Article

\title{
Simulation-Based Positioning of Circular Economy Manager's Skills in Construction Projects
}

\author{
Jarosław Górecki (D) \\ UTP University of Science and Technology, Faculty of Civil and Environmental Engineering and Architecture, \\ prof. S. Kaliskiego 7, 85-796 Bydgoszcz, Poland; gorecki@utp.edu.pl
}

Received: 5 December 2019; Accepted: 24 December 2019; Published: 26 December 2019

\begin{abstract}
Circular economy (CE) is an emerging economic model based on the endless circulation flow of resources creating additional value. In temporary organizations such as construction projects, all administrative decisions are crucial for final success. One of the ideas is to enroll a circular economy manager (CEMR) and put him in an organizational structure. Implementation of the CE concept should be the effort of the entire project team. However, actions specific to the innovative nature of the procedures related to the $\mathrm{CE}$ in construction projects require additional support. It can be provided by professionals who can adapt a wide spectrum of knowledge to be used for promoting $\mathrm{CE}$ in the execution of construction processes. CEMRs can play the role of patrons of the CE issues because they support project managers in saving material resources in construction projects. The symmetry between visible outcomes of the $\mathrm{CE}$ idea and the employment of an extra manager has contributed to the development of the CEMR selection criteria model. However, effective recruitment for such a post may be a bit complicated for decision-makers, especially when CE is still enigmatic, as its procedures are quite undiscovered. All in all, the multi-criteria decision-making problem forces one to prepare the list of selection criteria and to rank them according to status in the hierarchy. This article shows prioritized criteria for selecting the CEMR based on the advanced literature review concluded after several expert-based reviews and calculated after some Monte Carlo simulations. The main purpose of this article is to help decision-makers in construction projects to perform a reliable recruitment process.
\end{abstract}

Keywords: circular economy; selection process; construction project; management; Monte Carlo

\section{Introduction}

Progressive urbanization of natural areas fosters biodiversity loss and climate changes. The rapid development of urban areas all over the world causes many serious environmental concerns, such as emissions, floods, etc. Fortunately, growing knowledge about the economic growth paradigm [1] and ecological consciousness [2,3] in societies (among consumers, decision-makers, etc.) makes it possible to realize that limited resources are not just about limited capital that governments and institutions have, but it is also-and perhaps mainly - a question of scarcity of resources itself [4]. Therefore, a concept of the ecological perspective gets more and more popular and, for many, balanced development is the only way to get rid of this problem. Ecological practices play a significant role in the sustainable growth of nations in many countries.

Sustainable production [5,6] can be described as an environmental protection strategy based on continuous, coordinated, preventive action with regard to processes aimed at increasing the efficiency of production and services as well as reducing the risk to people and the natural environment [7]. The sustainable production framework links the production process with the concept of reducing the use of resources and the environmental impact of the product. Therefore, it applies to all stages of the product life cycle-from cradle to grave and from design to disposal [8]. 
More and more businesses are developing sustainable manufacturing systems $[9,10]$ and recruiting experts to their research and development $(R \& D)$ departments in search of new or more effective technologies. There are numerous issues waiting to be addressed, however.

A holistic approach is necessary for effective decision making connected with sustainable development [11] that aims to improve the quality of life while maintaining social equality, biodiversity, and variety of natural resources [12]. It means that considerations of economic issues should take into account their impact on social aspects, policies and the natural environment. For this purpose serves the circular economy (CE) concept [13-17].

The European Union's action plan for the circular economy [18] announced in 2015 by the European Commission is a response to the previously mentioned challenges. Legislative initiatives aim to reconcile environmental and business interests. The package is treated as a clear signal for all market players that full implementation of new ecological and raw materials policy is a priority for European decision-makers. The circular economy, according to the report, will boost the competitiveness of the EU by protecting businesses from resource scarcity and volatile prices, helping to create new business opportunities as well as innovative and more efficient ways to produce and consume.

According to the European Commission, certain sectors are facing particular challenges in the context of the circular economy due to the characteristics of their products or value chains, their environmental footprint and potential dependence on resources $[19,20]$ from outside Europe. As a result, the action plan enumerates five priority areas that require a specific approach:

- Plastics;

- Food waste;

- Critical raw materials;

- Construction and demolition;

- Biomass and bio-based products.

The above conclusions indicate that the construction industry is problematic and is responsible for the growing amount of waste that does not return to the value chain. It is also a very energy-intensive industry. In the United Kingdom, for example, annual emissions associated with the embodied energy required to produce all kinds of materials needed are over $10 \%$ of the UK's total emissions [21]. Strategies to reduce the energy demand for buildings and infrastructure are rapidly evolving that go beyond the maintenance phase and include the energy demand required for the production of the materials phase as well. According to Barrett et al. [21], there are many ways to minimize energy demand by evolving activities in the construction sector. A decreased use of materials through better design and manufacturing procedures as well as increased re-use and recycling rates are just the most evident examples. Cooper et al. [22] describe the circular economy approaches and estimate their potentials in construction as large.

A preliminary observation of project-based organizational structures focused on the roles of personnel responsible for managing environmental aspects of production reveals presumed neglect in this area. There is low popularity in general [105 results for "circular economy manager" in Google browser and one record [23] in ScienceDirect database (both numbers retrieved 17 December 2019)] and practically lacking in construction sector [17 results for "circular economy manager", "construction project" in Google browser and zero records in ScienceDirect database (both numbers retrieved 17 December 2019)] of circular economy manager posts. The above search results indicate, however, that the idea of establishing circular economy manager (CEMR) is not completely unfounded, because the first symptoms of this phenomenon appear in the economic sphere. The presumption confronted with an inevitable transition of the construction industry into circular economy opens a new, undiscovered scientific gap for assuring a list of the most important competencies of circular economy manager. 
The study was motivated by the question of whether or not project-based organizations like many construction companies note the necessity of hiring specialists on separate posts responsible for managing issues connected with this new business model and the philosophy of construction project execution based on closed-loop principles.

In the literature, some signs of such an attitude are present; however, the majority of examples only gently touch this problem, recalling the post: sustainability manager [24-27], environmental manager [28-31], or site waste manager [32-35].

However, interest should be also addressed regarding the existence of the symmetrical relationship, which has a dual character in this case. On the one hand, better functioning of the CE idea is achievable when the CEMR is employed in an organization. On the other hand, the effectiveness of the CEMR is greater the more thoroughly implemented the idea of $\mathrm{CE}$ in the organization is.

Therefore, an important decision-making process to be made by a construction company is the circular economy manager selection. This facilitates the fit of the project organizational structure to the new approach and choosing the right person that meets requirements connected with the post. A recruitment phase in construction companies is quite difficult and time-consuming and does not guarantee final success. Having a selection procedure pattern for the circular economy manager in construction projects may allow companies to avoid unnecessary costs and time wasted. The most important challenge is to identify selection criteria regarding what, in case of such a niche, may be very difficult due to lack of experience and case studies. Therefore, CE needs more complex problem solving skills, resource management capabilities, process skills and technical skills compared to the rest of the economy [36].

A review of the literature in the field of construction project management reveals a great interest in material resource issues categorized in symmetry with current sustainability problems. The author's proposal is a reply to these needs. It consists of employing the CEMR and putting him in a project structure similarly to the risk manager (RMR) or the quality manager (QMR).

The CEMR in the construction project should have an independent position and be subordinated only to the top management of the project (PMR).

The aim of the article is to launch a discussion on this topic, because the idea of employing a CEMR is innovative and has not been discussed widely in the literature yet. Indication of the problem along with its structuring in the article is based on the author's concept of the CEMR selection criteria model prepared on the basis of opinions of stakeholders of construction projects and gathered in the course of the study.

In general, there is a lack of knowledge about how to conduct a recruitment process to select the best candidates on a circular economy manager post in a construction project. A crucial question is what factors are influencing a successful decision. This paper aims to prioritize them in a clear, replicable way. It allows stakeholders of the construction projects to make more reliable and therefore less expensive decisions. The following research questions should, therefore, be formulated:

1. Is it necessary to employ circular economy managers to construction projects?

2. Is it possible to create one coherent model of the selection of circular economy managers in construction projects?

3. Can decision-makers make more reliable decisions in a process of CEMR selection?

In order to get rid of the confusion coming from the questions mentioned above, a survey-based study was performed and followed by the Monte Carlo simulation. This paper is organized, apart from the Introduction, into five main sections. The second chapter describes theoretical considerations about a topic of the research; the third one shows methods that can be used in the research. Criteria and selection models of CEMR are presented in the fourth chapter, which is followed by the research results in the fifth chapter. The last part of this article discusses the findings and provides ideas for future research. 


\section{Theoretical Framework}

This part describes a theoretical context of the research on the circular economy manager selection problem. The literature review provides a better explanation of the circular economy idea and its connections with construction management processes.

\subsection{Circular Economy (CE) in the Construction Sector}

Circular economy (CE) appears as an interesting concept of reducing negative externalities of human economic activity by finding new concepts of the flow of matter in manufacturing processes, assuming its closed-loop circulation. As a result, the CE-based systems allow one to preserve waste generation. They are created to save resources when the product life cycle comes to an end, allowing them to be reused and thus to create another value. The CE concept attracts decision-makers from various industries. Its application is particularly important in the construction sector, which is featured by close relations (direct interference) with the natural environment. The industry is one of the main waste generators and also one of the least environmentally friendly branches of the economy [37]. The limited resources force us to seek new technologies of waste recovery that can convert outputs of one production system into inputs of another (new) production system. The construction sector contributes significantly to $\mathrm{CO}_{2}$ emissions. Many of these emissions are generated in the manufacturing process of the construction materials. For example, in the Netherlands, concrete is responsible for $5 \%$ of global CO2 emissions [38]. CE can be considered at various levels both in the objective (in relation to buildings, structures and their parts) and in the subjective perspective (in relation to construction companies, workers, etc.).

During the construction process, huge amounts of resources are used, which results in the generation of significant amounts of waste, energy consumption and the production of harmful emissions into the environment. Also, it has a significant impact on many other sectors. There are many difficulties associated with finding the best practices in strategic and operational decision-making [15].

It is necessary to notice the life cycle of construction projects. It begins at the "cradle" - a moment of creation of an idea-and finishes at the grave after the demolition of a structure. In order to protect the environment and natural resources, the construction materials used for the construction project must be fully or partially recycled and reused (they must be "reborn").

Working in the construction industry requires both theoretical knowledge as well as practical experience and good abilities of the identification of global trends as well as local conditions. Therefore, a great deal is required of managers working in this sector.

\subsection{Implementation of $C E$ in Construction Project Management (CPM)}

The following changes precede the introduction of the CE in the construction industry. Firstly, the industry needs to be prepared technically for more efficient business models, including knowledge of more sustainable production systems, new organizational structures, etc. In addition, to benefit from the transition, the industry must be prepared with new technologies, services, management models, and digital platforms. The consumer must then be notified about the CE's financial and environmental benefits. However, it is not just the construction phase itself that needs to be evolved. This includes also a significant change in ways of maintaining a house, a road or other types of infrastructure. Secondly, the industry must generate and promote reliable measures to ensure that the condition of the company is a factor in its propensity to implement the CE. This measurement was proposed in the literature by Nuñez-Cacho et al. [15,39]. On the other hand, this article is intended to fill another research gap - the creation of fundamentals for CE-based construction project management relying on stakeholders' awareness of the role of circular economy manager and his competences being valued in the recruitment process.

Implementation of circular economy in construction projects may result in a higher value of their products, including increased profitability or reduction of costs in the project life cycle [40] by reduced 
consumption of resources as well as external factors such as higher built environment quality, lower emissions, etc.

The main goal of construction companies implementing strategies based on CE should be to achieve high project management maturity, taking into account the closed-loop production rules. This approach can be called circular economy maturity (CEM) [41]. Such an attitude in CPM is reflected in the competences of project team members, including the circular economy manager (CEMR). It is also necessary to create an environmental risk management plan in the project and risk capital to cover potential losses and unexpected increases in costs related to environmentally friendly attitudes [42], including the implementation of $\mathrm{CE}$.

The project management maturity can be observed in a company when its successes are treated as concurrent with successes of implemented projects. The project manager is responsible for achieving the project goals, whereas the circular economy manager should support him by enhancing competencies specifically related to closed-loop production.

The ability of the effective CPM is often determined by a reliable risk management plan in the project and risk capital to cover possible losses related to the project implementation. The project management maturity understood in this way manifests itself mainly in the selection of competent project team members. Therefore, it seems obvious that a reliable recruitment process resulting in right personnel selection helps in achieving the project management maturity by construction companies.

The next part of the article focuses on methods useful in the selection process of circular economy managers in construction projects.

\section{Methods}

This part describes the circular economy manager recruitment problem from the point of view of methods that can be used to create a reliable selection framework.

\subsection{Overview of Methods}

Decision theory has been a field of research for many years. It deals with situations in which decision-makers make a choice among given alternatives. Many studies have been published about this comprehensive issue. In the case of this research, the choice is among a group of candidates who are being considered for the CEMR post in construction projects. A brief overview of recent decision-making methods is useful, considering CEMR selection is ultimately about the decision of who will be responsible for circular economy issues in a construction project and if such a strategy will eventually be successful (and for whom) or not.

Choosing the right method for circular economy manager selection determines the desired stakeholder's engagement, causes a general acceptance of such an activity, and leads to the final success of the CE implementation process. Therefore, in this article, it is useful to present a variety of possible methods (Table 1) retrieved from the literature.

Table 1. Multi-criteria decision-making methods in project manager selection (PMS).

\begin{tabular}{cccc}
\hline Method & References & Method & References \\
\hline ANFIS & {$[43]$} & (Fuzzy) DEMATEL & {$[44]$} \\
ARAS & {$[45,46]$} & Fuzzy MCDM & {$[47,48]$} \\
Computing with words & {$[49]$} & (Fuzzy) SAW & {$[50,51]$} \\
COPRAS-G & {$[52]$} & (Fuzzy) TOPSIS & {$[53]$} \\
Delphi and fuzzy linguistic & {$[54,55]$} & Guzzy) VIKOR & {$[56,57]$} \\
(Fuzzy) AHP & {$[43,58-61]$} & Grey Relational Analysis & {$[62]$} \\
(Fuzzy) ANP & {$[44,63]$} & IPMA Competence Baseline & {$[64]$} \\
Fuzzy Comprehensive Evaluation & {$[65]$} & Principal Component Analysis & {$[66]$} \\
Fuzzy curves & {$[67]$} & Hybrid methods & {$[68]$} \\
(Fuzzy) Data Envelopment Analysis & {$[69,70]$} & {$[43,44,54,55,71-76]$} \\
\hline
\end{tabular}

AHP, Analytical Hierarchy Process; ANP, analytical Network Process; DEMATEL, Decision MAking Trial and Evaluation Laboratory; MCDM, Multiple-Criteria Decision-Making; SAW, Simple Additive Weighting; TOPSIS, Technique for Order of Preference by Similarity to Ideal Solution; VIKOR,Vise Kriterijumska Optimizacija I Kompromisno Resenje; COPRAS-G = Grey COmplex PRoportional Assessment; ARAS = Additive Ratio Assessment. 
Apart from different algorithms useful in the selection and ranking of alternatives, there are a variety of criteria weighting methods for personnel selection problems. Among the most significant tools, one can consider analytical hierarchy process (AHP) [45,70,77], analytical network process (ANP) [70], stepwise weight assessment ratio analysis (SWARA) [46,78-81], factor relationship (FARE) [77], linguistic weighted average (LWA) [49,67], average of normalized columns (ANC) [59], weighted aggregated sum product assessment (WASPAS) [82], KEmeny median indicator ranks accordance (KEMIRA) [83], or fuzzy weighted averaging (FWA) [72]. Also, the superiority and inferiority ranking (SIR) method [84] or the best-worst method (BWM) [85] have potentially wide application in weighting criteria for MCDM.

As one can observe, there are many interesting and comprehensive MCDM methods used for personnel selection, including hybrid methods. However, for the problem highlighted in the article for the CEMR selection process, it is proposed to use a simple but efficient way of reliability-based recruitment that is useful in construction projects and is described below.

\subsection{Description of the Selected Method}

The research was conducted from October 2018 to January 2019. A graphical summary of the selected method is presented in Figure 1. At the early stage of the research covering a conceptual phase, the literature study [database: ScienceDirect; keywords (multiple combination): circular economy, manager, construction, construction project, construction management, multi-criteria decision-making methods, uncertainty, risk; years: 2010-2019] was performed to provide a basis for a definition of the problem, an initial expert brainstorming and a specification of the research methods. The expert sessions included professionals (35-68 years old) directly related to the companies operating in the construction sector, i.e., members of the Polish Chamber of Civil Engineers. When selecting these experts, their professional skills in the field of construction management were taken into account (at least 10 years of experience). All of them were directly involved in a minimum of three construction projects.

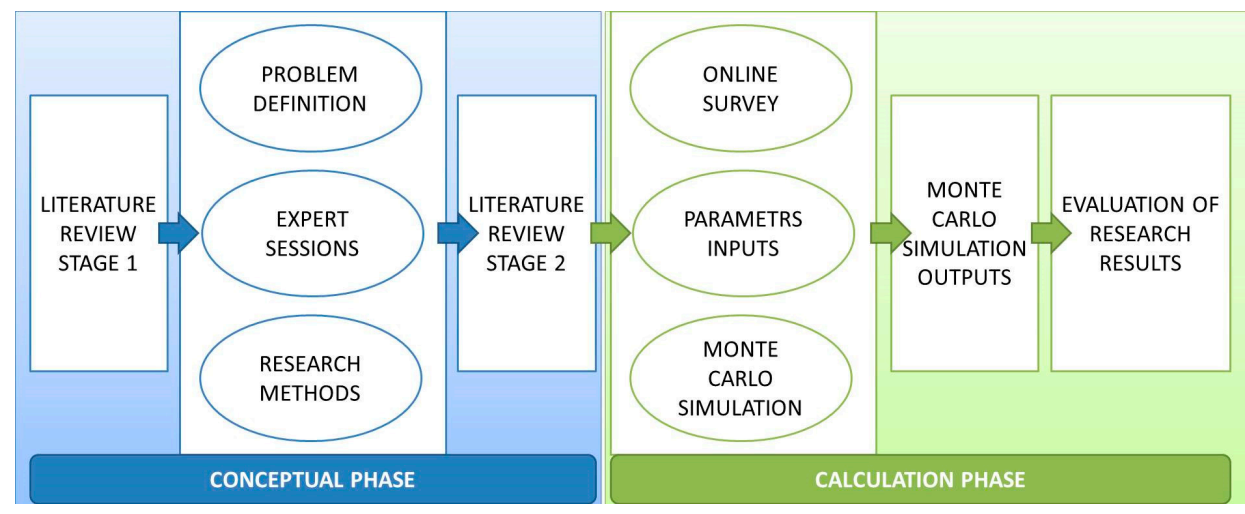

Figure 1. Graphical summary of the selected method.

Next, a second stage of the literature review [database: ScienceDirect; keywords (multiple combinations): green jobs, circular economy, manager, competence, leadership, selection criteria, skills, competencies, hierarchy, construction, construction project, construction management; years: 2010-2019] was done. This time, the most important purpose was to identify selection criteria for managers in construction projects especially suitable for the circular economy area. A further step of the research covered the quantitative process, which consisted of:

- An online survey performed on platform SurveyMonkey (www.surveymonkey.com) intended for collecting opinions about the criteria priorities and probability parameter inputs connected with particular selection criteria;

- Configuration of inputs of the model;

- $\quad$ Performance of simulation of the model using @Risk application (www.palisade.com). 
One purpose of the research was to show an opinion about the selection criteria of circular economy manager in construction projects, which is a proposal of the survey's author for better management by indicating and assessing a hierarchy of the competencies required from candidates to this position (deterministic approach). The second goal was to verify a reliability level of the decision-making process of the candidate selection based on the given criterion and to check differences between deterministic and probabilistic attitudes towards the ranking of skills.

The survey was carried out in January 2019. The questionnaire, divided into 18 questions on eight pages, was launched on the Internet platform, and its link address was sent to civil engineers, scientists and experts of building research and related fields, including project management, real estate and construction, united at the Cooperative Network for Building Researchers (CNBR) Yahoo Group.

Respondents were asked to respond to two initial questions about their experience in the area of research, ten further questions concerning importance and selection reliability of competencies expected from circular economy managers in construction projects divided into six groups (basic skills, complex problem solving skills, resource management skills, social skills, systems skills and technical skills), and they had an opportunity to leave feedback about a matter of the study.

Later, received responses from the survey were incorporated into a model of recruitment. The model is based on all 68 competencies-factors responsible for successful decision-making aimed at selecting the best candidates for the CEMR posts in construction projects. As each such decision is prone to risk, a multi-criteria decision-making procedure based on simulations, thus enabling one to take into account risk factors, was considered as the most suitable in this phase of the research.

Another purpose of the survey was to determine the hierarchy of the requirements expected from the potential CEMRs as well as to estimate the parameters of probability distributions, which reflect the accuracy of meeting expectations with respect to the candidates' reliability ( $R$, probability of success) of the selection. In literature, one can find many methods connected with different criteria weighting techniques $[52,62,69]$. A level of possible deviations from predictions, that is, risk level $(\check{R}$, probability of failure) was discovered simultaneously because, according to the reliability theory, the following equation exists:

$$
\mathrm{R}=1-\check{\mathrm{R}}
$$

The term risk refers to variability in the outcome of decisions. Thus, if it is assumed that the personnel selection based on given criteria is a decision made by someone who is responsible for a recruitment process, then the risk may be understood as a difference between her/his expectations to a candidate and its real performance. However, at the same time, this situation is associated with particular levels of probability of occurrence. Most risk quantifications involve subjective judgement. Different experts in the area might have quite different assessments of the same issue. On the basis of the survey, there were collected probabilities of occurrence of the particular factor needed for the risk analysis in the @Risk application. The analysis is a quantitative method that determines the probability distributions of the outcomes resulting from decisions. This technique can be described in four steps:

1. Developing a model—problem definition in Microsoft Excel;

2. Identifying inputs and outputs-to set inputs, to specify their possible values with probability distributions, and to define outputs that should be analyzed;

3. Analyzing the model with simulation - to run various scenarios with sampled values of inputs to determine the probability distributions of outputs;

4. Making a decision — to make informed choices on the basis of the simulation results.

There are many methods of simulation, but of special interest are Monte Carlo (MC) simulations. These comprise a powerful method to estimate the model results under risk factors. For this purpose, there are needed values that are drawn in a random way from an input probability distribution. It is performed repetitively until the total number of iterations finishes. This process is called sampling. In the research, the Latin hypercube sampling method was used. It is designed to avoid the clustering, and all values in the input distribution have a better chance at being sampled. 
The Monte Carlo simulation method of random variables is currently used in all branches of empirical science. Its application in data analysis is generally based on the fact that operations on real sets of measurement data (prone to an error) are carried out on-by imitating them-random sets generated by a computer.

As a result of the simulation proposed in this paper, the probability distributions for individual criteria for the assessment of candidates are obtained. Although the Monte Carlo simulation method has been thus far used to analyze employee selection factors, its current applications in this area do not refer to circular economy manager in construction projects, and, what is more, do not go deeper into the structure of requirements for candidates, which was noticed in this work as necessary. Therefore, the application of the Monte Carlo simulation to the risk analysis of CEMR selection-supporting decision making-proposed in this article is, without any doubt, an innovative solution.

\section{Criteria and Selection Model of CEMR}

A role of CEMR is to mobilize team members and maintain good relations with all project stakeholders, especially in matters related to all closed-loop production processes. The CEMR should have the following competencies basically characterizing managers, i.e., communication (building relationships, leadership), the strength of authority and negotiation (seeking compromises, treating conflicts and crises as opportunities, not threats), as well as commitment and motivation (faith in the project). However, the CEMR is a special type of manager for whom an ordinary level of competence is not enough. Therefore, it is required to establish a unique competency framework that can be useful for construction companies and other entities involved in construction projects executed according to the CE principles, recruiting on posts of senior management staff responsible for CE issues.

Based on the literature, a list of criteria for CEMR in construction projects was specified. All criteria were divided into basic, universal criteria (UC) and those related to construction industry-specific criteria (SC). All of them are present in six groups adapted after Burger et al. [36], which are shown in Table 2:

- $\quad$ Basic skills (BS): facilitate learning or self-development;

- $\quad$ Complex problem solving skills (CPSS): useful in solving different problems connected with a project in complex, real circumstances;

- $\quad$ Resource management skills (RMS): enable efficient resource allocation in a project;

- Social skills (SLS): useful for managing people in achieving project goals;

- $\quad$ Systems skills (SSS): facilitate understanding, monitoring and development of the whole context of a project;

- $\quad$ Technical skills (TS): useful for operating technical and technological aspects of a project.

Table 2. List of CEMR criteria for construction projects according to the literature.

\begin{tabular}{|c|c|c|c|}
\hline Group & Name of Criterion & $\begin{array}{l}\text { Type of } \\
\text { Criterion }\end{array}$ & References \\
\hline \multirow[t]{13}{*}{ Basic skills (BS) } & Active learning & UC & [36] \\
\hline & Active listening & UC & [36] \\
\hline & Critical thinking & UC & [36] \\
\hline & Emotional resilience & UC & [86] \\
\hline & Learning strategies & UC & [36] \\
\hline & Mathematics & UC & [36] \\
\hline & Monitoring & $\mathrm{UC}$ & [36] \\
\hline & Motivation & UC & [86] \\
\hline & Reading comprehension & UC & [36] \\
\hline & Science (applicability to solve problems) & UC & [36] \\
\hline & Self-awareness & UC & [86] \\
\hline & Speaking & UC & [36] \\
\hline & Writing & UC & [36] \\
\hline
\end{tabular}


Table 2. Cont.

\begin{tabular}{|c|c|c|c|}
\hline Group & Name of Criterion & $\begin{array}{l}\text { Type of } \\
\text { Criterion }\end{array}$ & References \\
\hline \multirow{8}{*}{$\begin{array}{l}\text { Complex problem } \\
\text { solving skills (CPSS) }\end{array}$} & Achieving (management) & $\mathrm{UC}$ & {$[86,87]$} \\
\hline & Complex problem solving & UC & [36] \\
\hline & Intuitiveness & UC & [86] \\
\hline & $\begin{array}{l}\text { Solve aesthetic and structural problems with limited supplied } \\
\text { components }\end{array}$ & UC & [88] \\
\hline & Strategic management competence and action competence & $\mathrm{UC}$ & {$[89,90]$} \\
\hline & Strategic perspective & $\mathrm{UC}$ & {$[86,87]$} \\
\hline & Understand failure mode and maintenance procedures & $\mathrm{UC}$ & [88] \\
\hline & Vision and imagination & UC & {$[86,87]$} \\
\hline \multirow[t]{7}{*}{$\begin{array}{l}\text { Resource management } \\
\text { skills (RMS) }\end{array}$} & Management of financial resources & UC & [36] \\
\hline & Management of material resources & SC & [36] \\
\hline & Management of personnel resources & SC & {$[36]$} \\
\hline & Resource management & SC & {$[86,87]$} \\
\hline & Time management & UC & {$[36]$} \\
\hline & Understand logistics and distribution processes & SC & [88] \\
\hline & Understand processes for reverse and re-manufacturing & SC & {$[88]$} \\
\hline \multirow[t]{16}{*}{ Social skills (SLS) } & Conscientiousness & UC & [86] \\
\hline & Coordination & UC & {$[36]$} \\
\hline & Developing (management) & UC & {$[86,87]$} \\
\hline & Developing followers into leaders & UC & [87] \\
\hline & Empowering (management) & $\mathrm{UC}$ & {$[86,87]$} \\
\hline & Engaging communication & UC & {$[86,87]$} \\
\hline & Influence & $\mathrm{UC}$ & [86] \\
\hline & Inspire followers to go beyond their own interest & UC & {$[87]$} \\
\hline & Instructing & UC & {$[36]$} \\
\hline & Interpersonal competence & UC & {$[89,90]$} \\
\hline & Interpersonal sensitivity & UC & [86] \\
\hline & Negotiation & UC & {$[36]$} \\
\hline & Normative competence & UC & {$[89,90]$} \\
\hline & Persuasion & UC & {$[36]$} \\
\hline & Service orientation & UC & [36] \\
\hline & Social perceptiveness & $\mathrm{UC}$ & {$[36]$} \\
\hline \multirow[t]{10}{*}{ System skills (SSS) } & Critical analysis and judgement & UC & {$[86,87]$} \\
\hline & Embracing diversity and interdisciplinary competence & UC & [89] \\
\hline & Foresighted thinking or anticipatory competence & UC & {$[89,90]$} \\
\hline & Judgment and decision making & UC & [36] \\
\hline & Systems analysis & UC & [36] \\
\hline & Systems evaluation & UC & {$[36]$} \\
\hline & Systems thinking competence & UC & {$[89,90]$} \\
\hline & Understand factors of the use experience & SC & [88] \\
\hline & Understand product wear by use & SC & [88] \\
\hline & Understand user expectations and perception of value & SC & [88] \\
\hline \multirow[t]{14}{*}{ Technical skills (TS) } & Assess material physical and chemical properties & SC & [88] \\
\hline & Equipment maintenance & SC & [36] \\
\hline & Equipment selection & SC & [36] \\
\hline & Installation & SC & [36] \\
\hline & Operation and control & SC & [36] \\
\hline & Operation monitoring & SC & [36] \\
\hline & Operations analysis & SC & {$[36]$} \\
\hline & Programming (IT skills) & $\mathrm{UC}$ & {$[36]$} \\
\hline & Quality control analysis & SC & {$[36]$} \\
\hline & Repairing (ability) & SC & [36] \\
\hline & Technology design & $\mathrm{SC}$ & {$[36]$} \\
\hline & Troubleshooting (with operating errors) & SC & [36] \\
\hline & Understand engineering functions of the product & SC & {$[88]$} \\
\hline & Understand the service experience and how to design services & SC & {$[88]$} \\
\hline
\end{tabular}

$\mathrm{UC}$, universal criteria; SC, specific criteria. 
All above 68 criteria $\left(\mathrm{X}_{\mathrm{BS}, 1}, \ldots, \mathrm{X}_{\mathrm{TS}, 14}\right)$ were analyzed through an expert assessment conducted online. Additionally, a model of personnel selection with a reference level of assessment of a candidate for CEMR in construction projects was created.

The @Risk application was used to perform Monte Carlo simulations of the proposed model. In each group $i=\langle 1 ; 6\rangle$, a deterministic mean was calculated. Then, simulation inputs were set, that is, the definition of distributions and the number of iterations.

For all $j$-cases in each $i$-group, Bernoulli distribution was defined by RiskBernoulli( $p$ ) parameter, which is used to model an event that either occurs with probability $p$ (value 1) or does not occur with probability $1-p$ (value 0 ). Next, simulation outputs were added. They were cut-off scores $\left(\operatorname{COS}_{i}\right)$ calculated for each group in the following way:

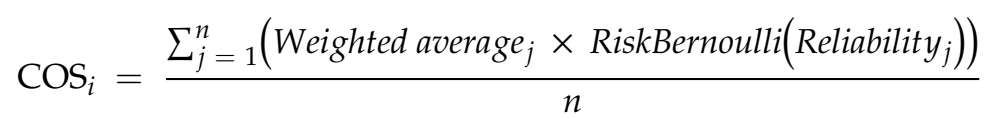

Some crucial results of the conducted survey and the simulated model are presented in the further part of the manuscript.

\section{Results}

The online survey included two basic parts. The first one contained two questions about the respondent's role played in professional life and her/his experience.

The largest number of respondents $(31.71 \%)$ were scientists involved in research on engineering economics, construction companies and related matters, followed by scientists of sustainability, circular economy and related areas (21.95\%), experts of circular economy, sustainable development and construction industry (17.07\% for each group), and others-five people related to the construction industry or CE but not considered as experts were a minority of the sample (12.20\%), as shown in Figure 1.

A structure of the respondents regarding their experience and seniority in the profession is presented in Figure 2.

\section{Q1 Your leading role}

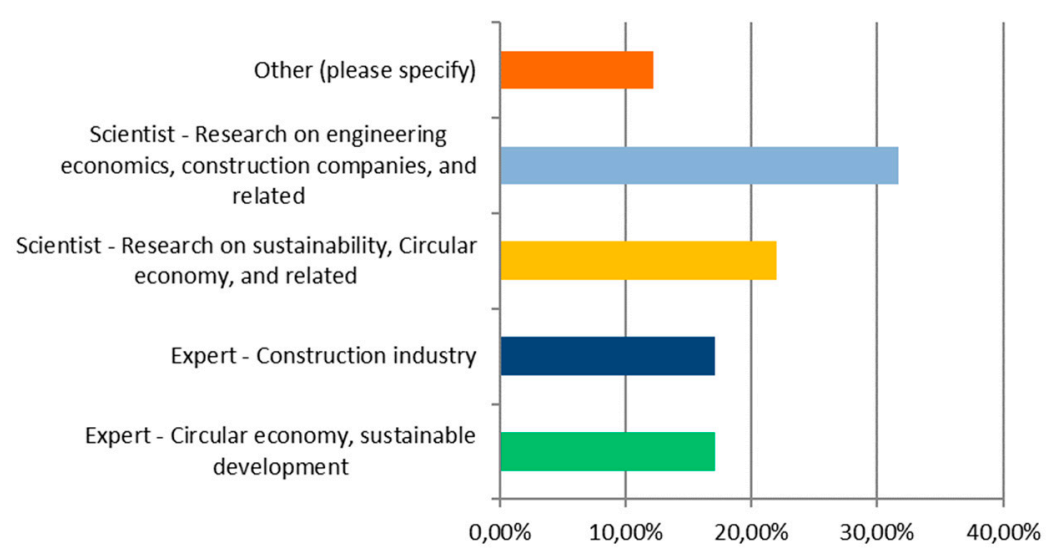

Figure 2. Leading roles of the sample.

Analyzing a professional practice of respondents (Figure 3), the largest was a group with over 15 years of experience $(36.59 \%)$, then $5-10$ years $(31.71 \%)$, and the smallest had less than five years of professional experience. 


\section{Q2 Your experience}

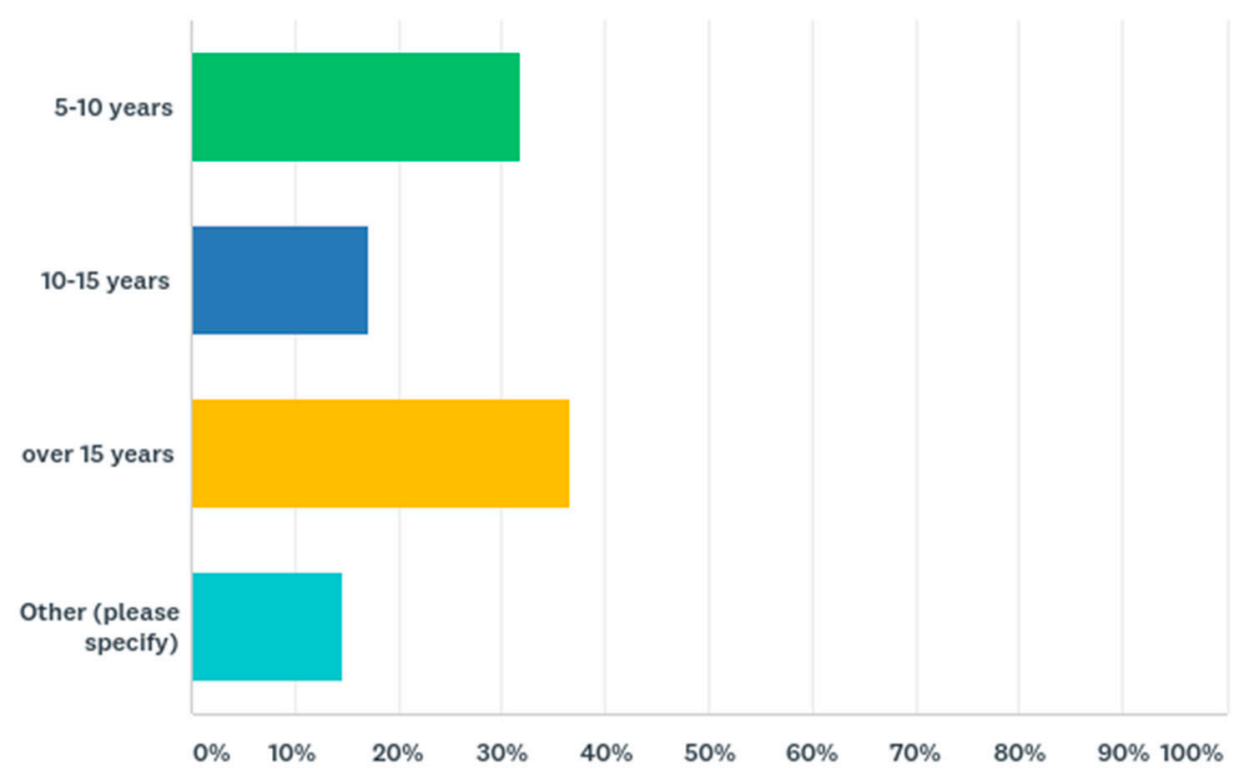

Figure 3. Declared experience of the sample.

In the second part of the survey, there were proposed 68 factors important during the decision-making process of recruitment on circular economy manager post in construction projects. They were divided into six groups: basic skills, complex problem solving skills, resource management skills, social skills, systems skills and technical skills.

The respondents assessed the importance of each factor, expressing the opinion numerically in a five-point scale based on Likert's approach to scaling responses in survey research: 1—strongly not important; 2-almost not important; 3-medium importance; 4-important; 5-very important. The collected dataset underwent a prioritizing process based on calculated weighted averages.

Table 3 presents the most important findings of the conducted research-the importance hierarchy of the competencies demanded from CEMR and their average accuracy of meeting expectations with respect to potential candidates.

Table 3. List of prioritised criteria for CEMR selection in construction projects according to the survey.

\begin{tabular}{ccccccc}
\hline Factor & Name of Criterion & $\begin{array}{c}\text { Weighted } \\
\text { Average }\end{array}$ & Min & Max & Rank & Reliability \\
\hline$X_{1,1}$ & Motivation & 4.41 & 1 & 5 & 1 & 81,48 \\
$X_{1,2}$ & Critical thinking & 4.37 & 1 & 5 & 2 & 81,11 \\
$X_{1,3}$ & Active learning & 4.19 & 1 & 5 & 3 & 81,11 \\
$X_{1,4}$ & Monitoring & 4.04 & 3 & 5 & 4 & 75,93 \\
$X_{1,5}$ & Active listening & 3.96 & 1 & 5 & $5-6$ & 75,19 \\
$X_{1,6}$ & Learning strategies & 3.96 & 1 & 5 & $5-6$ & 76,67 \\
$X_{1,7}$ & Science (applicability to solve problems) & 3.89 & 1 & 5 & 7 & 79,26 \\
$X_{1,8}$ & Self-awareness & 3.85 & 2 & 5 & 8 & 74,07 \\
$X_{1,9}$ & Reading comprehension & 3.81 & 2 & 5 & 9 & 71,85 \\
$X_{1,10}$ & Emotional resilience & 3.74 & 2 & 5 & 10 & 71,48 \\
$X_{1,11}$ & Speaking & 3.70 & 1 & 5 & 11 & 68,89 \\
$X_{1,12}$ & Mathematics & 3.56 & 1 & 5 & 12 & 71,48 \\
$X_{1,13}$ & Writing & 3.52 & 1 & 5 & 13 & 68,15 \\
\hline
\end{tabular}


Table 3. Cont.

\begin{tabular}{|c|c|c|c|c|c|c|}
\hline Factor & Name of Criterion & $\begin{array}{l}\text { Weighted } \\
\text { Average }\end{array}$ & Min & $\operatorname{Max}$ & Rank & Reliability \\
\hline$X_{2,1}$ & Vision and imagination & 4.48 & 2 & 5 & 1 & 78 \\
\hline$x_{2,2}$ & Strategic perspective & 4.4 & 2 & 5 & 2 & 78 \\
\hline$x_{2,3}^{2,2}$ & CompleXproblem solving & 4.36 & 3 & 5 & 3 & 78,8 \\
\hline$X_{2,4}$ & Achieving (management) & 4.32 & 3 & 5 & 4 & 82,4 \\
\hline$x_{2,5}$ & $\begin{array}{l}\text { Understand failure mode and maintenance } \\
\text { procedures }\end{array}$ & 4.16 & 1 & 5 & 5 & 82 \\
\hline$X_{2,6}$ & $\begin{array}{l}\text { Strategic management competence and action } \\
\text { competence }\end{array}$ & 4.08 & 2 & 5 & 6 & 74,8 \\
\hline$X_{2,7}$ & Intuitiveness & 4 & 2 & 5 & 7 & 73,2 \\
\hline$X_{2,8}$ & $\begin{array}{l}\text { Solve aesthetic and structural problems with } \\
\text { limited supplied components }\end{array}$ & 3.76 & 1 & 5 & 8 & 69,2 \\
\hline$X_{3,1}$ & Management of material resources & 4.45 & 3 & 5 & $1-2$ & 87,27 \\
\hline$X_{3,2}$ & Resource management & 4.45 & 3 & 5 & $1-2$ & 83,64 \\
\hline$x_{3,3}$ & Time management & 4.32 & 3 & 5 & 3 & 81,82 \\
\hline$x_{3,4}$ & Management of personnel resources & 4.27 & 3 & 5 & 4 & 83,64 \\
\hline$X_{3,5}$ & Management of financial resources & 4.18 & 2 & 5 & $5-6$ & 82,73 \\
\hline$x_{3,6}$ & $\begin{array}{l}\text { Understand processes for reverse and } \\
\text { re-manufacturing }\end{array}$ & 4.18 & 1 & 5 & $5-6$ & 78,64 \\
\hline $\mathrm{X}_{3,7}$ & $\begin{array}{l}\text { Understand logistics and distribution } \\
\text { processes }\end{array}$ & 4.14 & 2 & 5 & 7 & 76,36 \\
\hline$X_{4,1}$ & Developing (management) & 4.21 & 3 & 5 & 1 & 78,42 \\
\hline$X_{4,2}$ & $\begin{array}{l}\text { Inspire followers to go beyond their own } \\
\text { interest }\end{array}$ & 4.11 & 2 & 5 & 2 & 74,21 \\
\hline$X_{4,3}$ & Coordination & 4.05 & 2 & 5 & $3-5$ & 76,32 \\
\hline$X_{4,4}$ & Empowering (management) & 4.05 & 2 & 5 & $3-5$ & 76,84 \\
\hline$X_{4,5}$ & Negotiation & 4.05 & 3 & 5 & $3-5$ & 78,95 \\
\hline$X_{4,6}$ & Engaging communication & 4 & 2 & 5 & 6 & 74,74 \\
\hline$X_{4,7}$ & Conscientiousness & 3.95 & 3 & 5 & $7-9$ & 76,84 \\
\hline$X_{4,8}$ & Interpersonal competence & 3.95 & 3 & 5 & $7-9$ & 70 \\
\hline$X_{4,9}$ & Persuasion & 3.95 & 3 & 5 & $7-9$ & 74,74 \\
\hline$X_{4,10}$ & Influence & 3.89 & 1 & 5 & $10-11$ & 75,26 \\
\hline$X_{4,11}$ & Instructing & 3.89 & 2 & 5 & $10-11$ & 76,84 \\
\hline$X_{4,12}$ & Developing followers into leaders & 3.84 & 1 & 5 & 12 & 75,26 \\
\hline$X_{4,13}$ & Interpersonal sensitivity & 3.79 & 2 & 5 & $13-14$ & 68,95 \\
\hline$X_{4,14}$ & Normative competence & 3.79 & 3 & 5 & $13-14$ & 76,32 \\
\hline$X_{4,15}$ & Service orientation & 3.74 & 2 & 5 & 15 & 71,58 \\
\hline $\mathrm{X}_{4,16}$ & Social perceptiveness & 3.68 & 1 & 5 & 16 & 68,42 \\
\hline$X_{5,1}$ & Systems evaluation & 4.32 & 3 & 5 & 1 & 80,53 \\
\hline$X_{5,2}$ & Critical analysis and judgement & 4.26 & 3 & 5 & $2-3$ & 78,42 \\
\hline$x_{5,3}$ & Systems analysis & 4.26 & 2 & 5 & $2-3$ & 77,89 \\
\hline$X_{5,4}$ & $\begin{array}{l}\text { Foresighted thinking -or anticipatory- } \\
\text { competence }\end{array}$ & 4.16 & 2 & 5 & $4-5$ & 78,42 \\
\hline$X_{5,5}$ & Systems thinking competence & 4.16 & 2 & 5 & $4-5$ & 75,79 \\
\hline$X_{5,6}$ & Judgment and decision making & 4.11 & 2 & 5 & 6 & 80 \\
\hline$x_{5,7}$ & $\begin{array}{l}\text { Understand user expectations and perception } \\
\text { of value }\end{array}$ & 4.05 & 2 & 5 & 7 & 75,79 \\
\hline$X_{5,8}$ & $\begin{array}{c}\text { Embracing diversity and interdisciplinary } \\
\text { competence }\end{array}$ & 3.89 & 1 & 5 & $8-9$ & 73,16 \\
\hline$X_{5,9}$ & Understand factors of the use experience & 3.89 & 1 & 5 & $8-9$ & 74,74 \\
\hline$X_{5,10}$ & Understand product wear by use & 3.84 & 1 & 5 & 10 & 74,74 \\
\hline
\end{tabular}


Table 3. Cont.

\begin{tabular}{lcccccc}
\hline Factor & Name of Criterion & $\begin{array}{c}\text { Weighted } \\
\text { Average }\end{array}$ & Min & Max & Rank & Reliability \\
\hline$X_{6,1}$ & Operation monitoring & 4.05 & 1 & 5 & 1 & 77,37 \\
$X_{6,2}$ & Equipment selection & 3.95 & 1 & 5 & 2 & 72,11 \\
$X_{6,3}$ & Operation and control & 3.89 & 2 & 5 & $3-4$ & 74,21 \\
$X_{6,4}$ & Operations analysis & 3.89 & 2 & 5 & $3-4$ & 77,37 \\
$X_{6,5}$ & Quality control analysis & 3.84 & 2 & 5 & $5-6$ & 73,68 \\
$X_{6,6}$ & Technology Design & 3.84 & 1 & 5 & $5-6$ & 68,42 \\
$X_{6,7}$ & Programming (IT skills) & 3.79 & 2 & 5 & $7-9$ & 78,42 \\
$X_{6,8}$ & Troubleshooting (with operating errors) & 3.79 & 2 & 5 & $7-9$ & 72,11 \\
$X_{6,9}$ & Understand engineering functions of the & 3.79 & 1 & 5 & $7-9$ & 77,37 \\
$X_{6,10}$ & product & & & & & \\
$X_{6,11}$ & Anderstand the service experience and how to & 3.74 & 1 & 5 & 10 & 74,74 \\
$X_{6,12}$ & design services & & & & & \\
$X_{6,13}$ & Assess material physical and chemical & 3.53 & 1 & 5 & $11-12$ & 64,74 \\
$X_{6,14}$ & properties & 3.53 & 1 & 5 & $11-12$ & 70,53 \\
\hline
\end{tabular}

The proposed 68 factors $\left(X_{i, j}\right)$ may be useful for a recruitment process. In the next step, the criteria divided into six groups were taken to further consideration.

Monte Carlo simulations of the proposed model were performed in the @Risk application. For $i$-group, a deterministic mean was calculated, and for all $j$-cases in each $i$-group, Bernoulli distribution was defined by RiskBernoulli( $p$ ) parameter in order to get probabilistic values. For example, "Operation monitoring" skill was coded with formula RiskBernoulli(0.7737), which returned a Bernoulli distribution with parameter 0.7737 . This had a $77.37 \%$ chance of returning 1 (understood as a success, "skill observed") and a $22.63 \%$ chance of returning 0 (understood as a lack of success, "skill not observed"). A number of iterations was set as 1000, which gave sufficient results (smoothed graphical results). Additionally, the cut-off scores $\left(\mathrm{COS}_{i}\right)$ were calculated for each group on the basis of Equation (2).

The aggregated results of the simulation are presented in Table 4. More details are given in Appendix A.

Table 4. Monte Carlo simulation results.

\begin{tabular}{cccccc}
\hline \multirow{2}{*}{ Factors } & \multirow{2}{*}{ Cut-Off Score Group } & \multicolumn{3}{c}{ Deterministic } & \multicolumn{3}{c}{ Probabilistic } \\
\cline { 3 - 6 } & & Mean & Min & Max & Median \\
\hline $\mathrm{X}_{\mathrm{BS}, \mathrm{j}}$ & Basic skills & 3.923 & 0.895 & 3.923 & 3.023 \\
$\mathrm{X}_{\mathrm{CPSS}, \mathrm{j}}$ & Complex problem solving skills & 4.195 & 1.100 & 4.195 & 3.180 \\
$\mathrm{X}_{\mathrm{RMS}, \mathrm{j}}$ & Resource management skills & 4.284 & 1.194 & 4.284 & 3.667 \\
$\mathrm{X}_{\mathrm{SL} S \mathrm{j}, \mathrm{j}}$ & Social skills & 3.934 & 1.487 & 3.934 & 2.954 \\
$\mathrm{X}_{\mathrm{SSS}, \mathrm{j}}$ & Systems skills & 4.094 & 1.610 & 4.094 & 3.263 \\
$\mathrm{X}_{\mathrm{TS}, \mathrm{j}}$ & Technical skills & 3.748 & 1.324 & 3.748 & 2.703 \\
\hline
\end{tabular}

The simulation approach to assess the hierarchy of CEMR selection criteria gives significant changes in the order of cut-off score groups used in the recruitment process of the right candidate for this position. From a deterministic perspective, the order of these groups is as follows:

1. Resource management skills;

2. Complex problem solving skills;

3. Systems skills;

4. Social skills;

5. Basic skills;

6. Technical skills. 
According to the simulation results, after taking into account the reliability of the candidate's compliance with the relevant requirements, the rearrangement in the order of the score groups can be observed:

1. Resource management skills;

2. Systems skills;

3. Complex problem solving skills;

4. Basic skills;

5. Social skills;

6. Technical skills.

The simulation data can be treated as a reference level of assessment of a candidate for CEMR in construction projects. In the next section, some peculiar findings are described.

\section{Discussion and Conclusions}

For a simulation-based positioning of circular economy manager's skills in construction projects, it is necessary to use a specific approach. It requires a detailed recognition of the most important skills needed in a given post. Besides, CEMR selection is a multi-criteria problem similar to the project manager selection process [62]. On the basis of this similarity, a model of selection criteria for the circular economy manager had to be built.

The most elevated requirements were observed for "Vision and imagination" (4.48), "Management of material resources" (4.45), and "Resource management" (4.45), whereas some technical skills such as "Equipment maintenance" (3.47) or the ability of "Repairing" (3.37) might be neglected. In fact, these abilities are suitable for lower managers or workers rather than CEMRs. After aggregation, the most important factors were grouped in "Resource management skills" (3.667 median), and the least important were "Technical skills" (2.703) modeled on contemporary employees during simple workshops or short training.

Circular economy manager selection appears as an important decision-making process in construction companies interested in the CE implementation [37]. A high level of complexity of issues related to CE makes that employment of the CEMR in construction projects seem inevitable. Such a transition requires adapting the project organizational structure to this new approach and selecting the right person to meet the detailed requirements connected with the post. A recruitment phase is usually time-consuming and therefore quite expensive for construction companies; what is more, it does not guarantee final success. The cut-offs, those being the results of the study, are the points separating successful and unsuccessful performers according to a standard established by the employer. Having a coherent model treated as a selection procedure pattern for the circular economy manager, construction companies may avoid unnecessary costs and time wasted. This model was presented in the article.

However, as always, there are different scenarios that may occur. One situation is observed when, as a result of an assessment based on the proposed model, the true positives are obtained. They are those who pass the selection test (beat the cut off scores in each group of factors), succeed on the job, and who perform satisfactorily afterwards.

The opposite situation is observed when candidates are correctly rejected as a result of the measurement, and there is a presumption—almost a certainty—that they would not be successful employees anyway, thus they are called true negatives. The third scenario is observed when people are rejected but would have performed well on the job if they had been hired. They are called false negatives. Finally, false positives describe individuals who are selected for the post but do not turn out to be a good choice. The research reveals that decision-makers can make more reliable selections in the process of the CEMR recruitment provided that they take the approach proposed in the article. 
Due to lack of experience and case studies, it was quite difficult to identify selection criteria for CEMR. Fortunately, the literature review brought several ideas that were confronted by a series of expert assessments. The results of the research revealed that complex problem solving skills, resource management skills, and system skills are very crucial in the CEMR selection process.

The main contribution of this article is the simulation-based positioning of skills of the circular economy manager. It was based on quantified expert opinions. The first stage provided a list of criteria that result from a deterministic approach. However, the results of the Monte Carlo simulation were quite unexpected. Despite small numerical discrepancies, the hierarchy changed significantly. Only the first ("Resource management skills") and the last ("Technical skills") groups of requirements stayed in the same position. The other aggregate lists swapped the order in neighboring pairs. This was, of course, due to the fact that the weights of individual skills are probabilistic, and the changing values of the simulated variables resulted in a different average level. Regardless, the experts' indications and their sensitivity when assessing individual skills are important as well. From this point of view, the selection of experts in the scientific process (see: conceptual phase, Figure 1) whose knowledge was used to construct the model was extremely important.

All in all, this evident gap in knowledge of how to conduct a recruitment process to select the best candidates on a circular economy manager post in construction projects was filled.

The symmetry, whose dual character was emphasized, should inspire decision-makers to take appropriate actions. On the one hand, it should be remembered that the CE idea brings greater effects when the CEMR works in an organization. On the other hand, the effectiveness of the CEMR is greater if the idea of $\mathrm{CE}$ is thoroughly implemented and well known in the organization. The above dependence determines how to search for solutions that guarantee the success of both the construction project and the company that executes it.

Besides, it is reasonable to emphasize the meaning of the simulation model, which is especially advisable for implementing new ideas. In this case, creating a new position in the structure of construction projects can be treated as an innovative solution. The collected expert opinions brought a number of ideas related to the specification of CEMR's skills that need to be prioritized.

\section{Limitations and Future Research Lines}

As was explained previously, the topic of this manuscript was worthwhile for scientific analysis even if we currently have an early stage of knowledge development in this area. The aim of the article was to start a discussion on this, because the idea of employing CEMR is very innovative.

However, there are still several problems that should be solved in future research:

1. The proposed model can be checked by other probability distribution patterns. Which of them are suitable, and how can one obtain reliable input parameters?

2. There might exist some correlations between factors. How can one measure them and implement the proposed model?

3. There are other methods supporting multi-criteria decision making in the personnel selection process. What other methods are suitable for the CEMR recruitment to construction projects?

4. What types of difficulties can managers face in a real-life selection of CEMR?

The survey should be continued to receive more experts' opinions to increase the accuracy of its results. It seems that some case studies may be helpful in confronting the theoretical approach of the model; however, there are no common examples of hiring CEMR in construction projects, thus we must wait for future research.

This study used a Monte Carlo simulation approach. The main contribution of this paper is the identification of the prioritized criteria for selecting CEMR candidates to construction projects. The proposed model gives six expert-based cut-off scores described by probability distributions. The outcomes of the research can help in making more reliable decisions connected with the CEMR selection process in construction projects. 
Funding: This research received no external funding.

Conflicts of Interest: The author declares no conflict of interest.

\section{Appendix A}

The detailed reports of the simulations are presented in Figures A1-A6. Each summary consists of two elements: graphical results (histograms, distribution charts, tornado charts) on the left side as well as numerical results (mainly statistics connected with the simulation) on the right side.

\section{@RISK Output Report for COS1 = L14}

Performed By: Jaroslaw Gorecki

Date: 17 Dec 2019

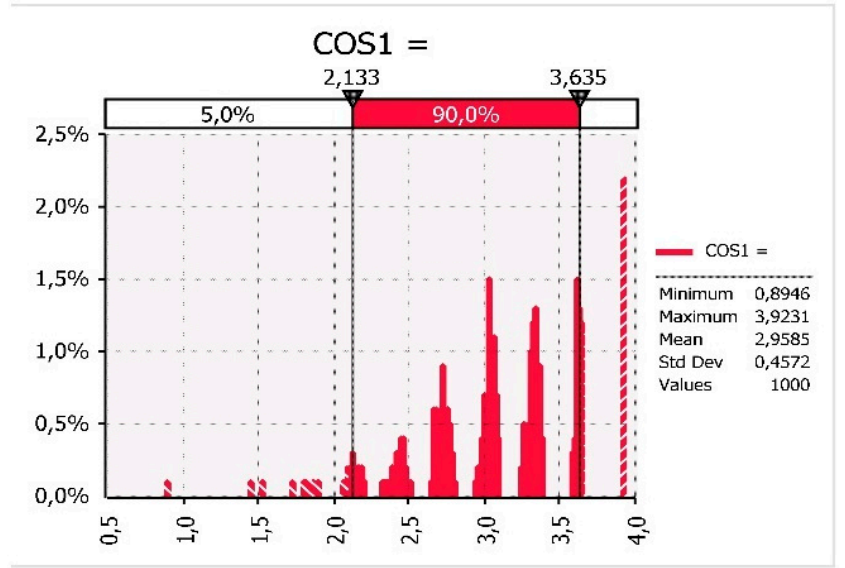

\begin{tabular}{l|l}
\hline \multicolumn{2}{l}{ Simulation Summary Information } \\
\hline Workbook Name & model.xlsx \\
\hline Number of Simulations & 1 \\
\hline Number of Iterations & 1000 \\
\hline Number of Inputs & 68 \\
\hline Number of Outputs & 6 \\
\hline Sampling Type & Latin Hypercube \\
\hline Simulation Start Time & $2019-01-31$ 10:17 \\
\hline Simulation Duration & $00: 08: 37$ \\
\hline Random \# Generator & Mersenne Twister \\
\hline Random Seed & 526537960 \\
\hline
\end{tabular}

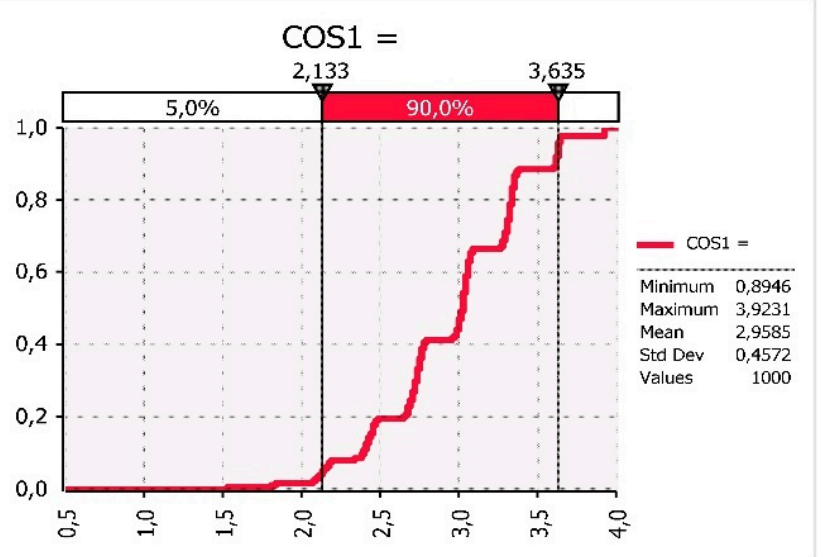

\begin{tabular}{|c|c|c|c|}
\hline \multicolumn{4}{|c|}{ Summary Statistics for COS1 = } \\
\hline \multicolumn{2}{|c|}{ Statistics } & \multicolumn{2}{|l|}{ Percentile } \\
\hline Minimum & 0,894615385 & $5 \%$ & 2,133076923 \\
\hline Maximum & 3,923076923 & $10 \%$ & 2,39 \\
\hline Mean & 2,958549231 & $15 \%$ & 2,441538462 \\
\hline Std Dev & 0,457150443 & $20 \%$ & 2,652307692 \\
\hline Variance & 0,208986528 & $25 \%$ & 2,700769231 \\
\hline Skewness & $-0,347327727$ & $30 \%$ & 2,726923077 \\
\hline Kurtosis & 3,074515488 & $35 \%$ & 2,749230769 \\
\hline Median & 3,023076923 & $40 \%$ & 2,780769231 \\
\hline Mode & 3,923076923 & $45 \%$ & 2,997692308 \\
\hline Left $X$ & 2,133076923 & $50 \%$ & 3,023076923 \\
\hline Left $P$ & $5 \%$ & $55 \%$ & 3,039230769 \\
\hline Right X & 3,635384615 & $60 \%$ & 3,053846154 \\
\hline Right P & $95 \%$ & $65 \%$ & 3,08 \\
\hline Diff $X$ & 1,502307692 & $70 \%$ & 3,296153846 \\
\hline Diff $P$ & $90 \%$ & $75 \%$ & 3,319230769 \\
\hline \#Errors & 0 & $80 \%$ & 3,333846154 \\
\hline Filter Min & Off & $85 \%$ & 3,353076923 \\
\hline Filter Max & Off & $90 \%$ & 3,612307692 \\
\hline \#Filtered & 0 & $95 \%$ & 3,635384615 \\
\hline
\end{tabular}

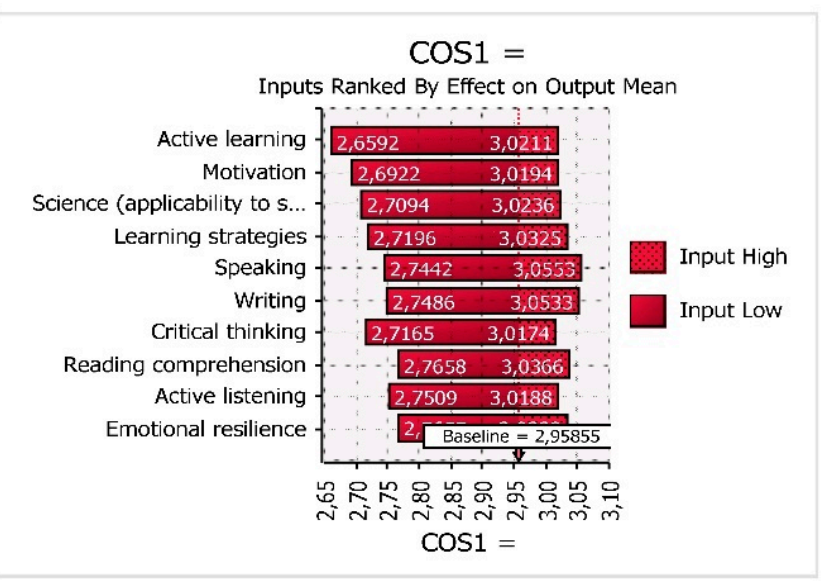

\begin{tabular}{|c|c|c|c|}
\hline Rank & Name & Lower & Upper \\
\hline 1 & Active learning & 2,659215385 & 3,021101923 \\
\hline 2 & Motivation & 2,692161538 & 3,019436538 \\
\hline 3 & \multicolumn{2}{|c|}{ Science (applicabilit 2,709357692 } & 3,023630769 \\
\hline 4 & Learning strategies & 2,719584615 & 3,032515385 \\
\hline 5 & Speaking & 2,744202564 & 3,055264103 \\
\hline 6 & Writing & 2,748607692 & 3,053323077 \\
\hline 7 & Critical thinking & 2,716453846 & 3,017372115 \\
\hline 8 & \multicolumn{2}{|c|}{ Reading compreher 2,765784615} & 3,036553846 \\
\hline 9 & Active listening & 2,750942308 & 3,018759341 \\
\hline 10 & Emotional resilience & 2,765692308 & 3,033243956 \\
\hline & & & \\
\hline & & & \\
\hline & & & \\
\hline & & & \\
\hline
\end{tabular}

Figure A1. Screenshot of the simulation results for the "basic skills" cut-off score group. 
Figure A1 relates to "Basic skills" cut-off score group, whereas other Figures A2-A6 describe results of: "complex problem solving skills", "resource management skills", "social skills", "systems skills" and "technical skills", respectively.

\section{@RISK Output Report for COS2 = L22}

Performed By: Jaroslaw Gorecki

Date: 17 Dec 2019
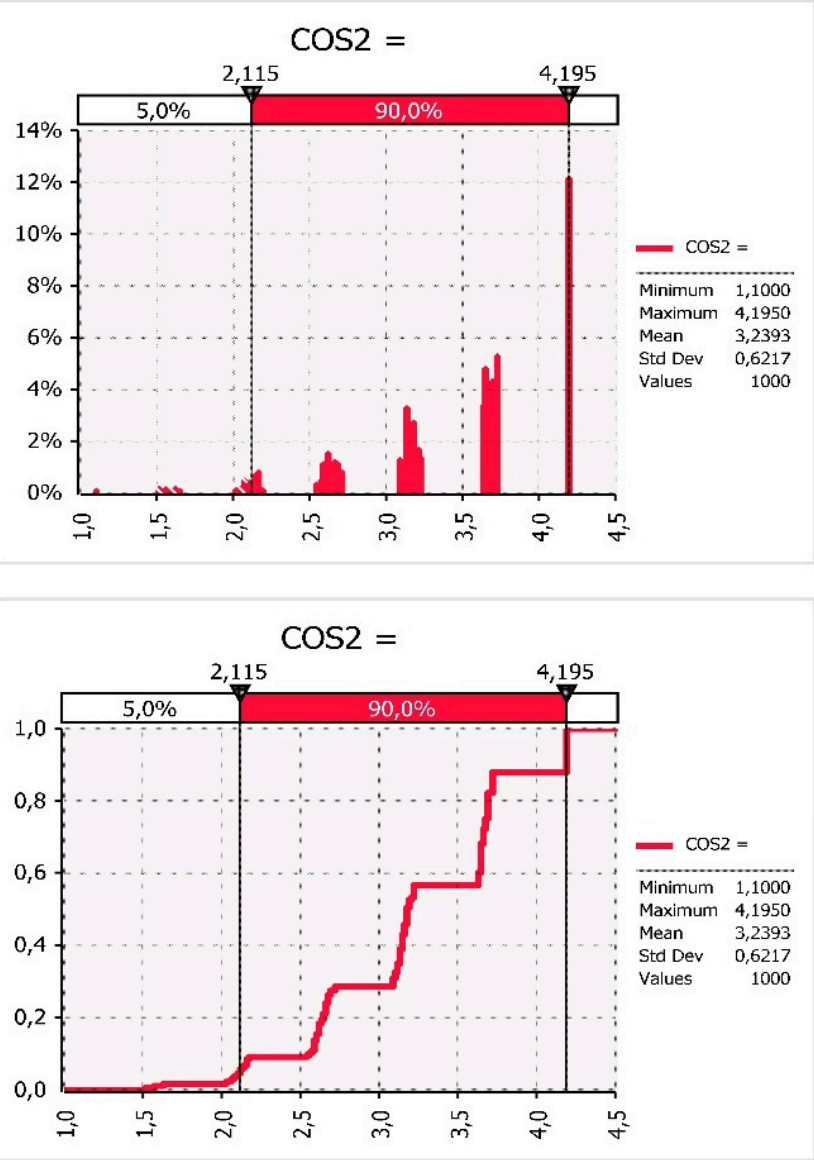

$\cos 2=$

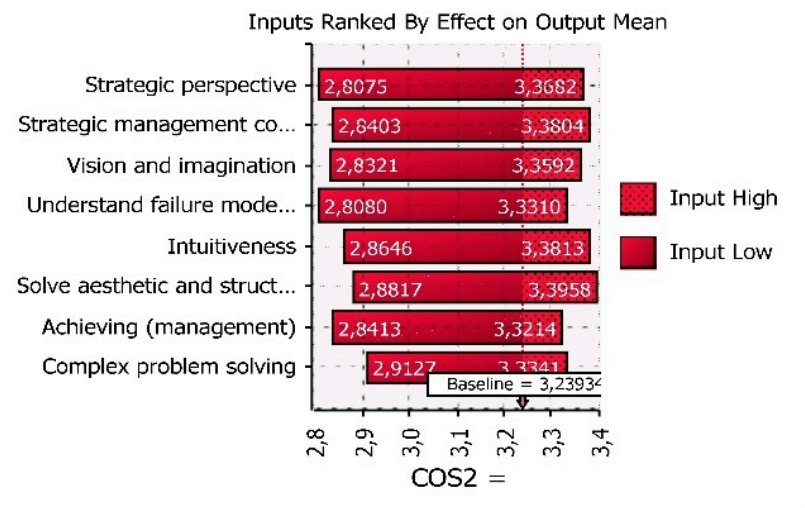

\begin{tabular}{|c|c|c|c|}
\hline \multicolumn{4}{|c|}{ Simulation Summary Information } \\
\hline \multicolumn{2}{|c|}{ Workbook Name } & \multicolumn{2}{|l|}{ model.xlsx } \\
\hline \multicolumn{2}{|c|}{ Number of Simulations } & \multicolumn{2}{|l|}{1} \\
\hline \multicolumn{2}{|c|}{ Number of Iterations } & \multicolumn{2}{|l|}{1000} \\
\hline \multicolumn{2}{|c|}{ Number of Inputs } & \multicolumn{2}{|l|}{68} \\
\hline \multicolumn{2}{|c|}{ Number of Outputs } & \multicolumn{2}{|l|}{6} \\
\hline \multicolumn{2}{|c|}{ Sampling Type } & \multicolumn{2}{|c|}{ Latin Hypercube } \\
\hline \multicolumn{2}{|c|}{ Simulation Start Time } & \multicolumn{2}{|c|}{ 2019-01-31 10:17 } \\
\hline \multicolumn{2}{|c|}{ Simulation Duration } & \multicolumn{2}{|c|}{$00: 08: 37$} \\
\hline \multicolumn{2}{|c|}{ Random \# Generator } & \multicolumn{2}{|c|}{ Mersenne Twister } \\
\hline \multicolumn{2}{|c|}{ Random Seed } & \multicolumn{2}{|c|}{526537960} \\
\hline \multicolumn{4}{|c|}{ Summary Statistics for COS2 = } \\
\hline \multicolumn{2}{|l|}{ Statistics } & \multicolumn{2}{|l|}{ Percentile } \\
\hline Minimum & 1,1 & $5 \%$ & 2,115 \\
\hline Maximum & 4,195 & $10 \%$ & 2,565 \\
\hline Mean & 3,23934 & $15 \%$ & 2,605 \\
\hline Std Dev & 0,621724783 & $20 \%$ & 2,64 \\
\hline Variance & 0,386541706 & $25 \%$ & 2,675 \\
\hline Skewness & $-0,412793555$ & $30 \%$ & 3,09 \\
\hline Kurtosis & 2,686262253 & $35 \%$ & 3,13 \\
\hline Median & 3,18 & $40 \%$ & 3,145 \\
\hline Mode & 4,195 & $45 \%$ & 3,165 \\
\hline Left $X$ & 2,115 & $50 \%$ & 3,18 \\
\hline Left $\mathbf{P}$ & $5 \%$ & $55 \%$ & 3,215 \\
\hline Right X & 4,195 & $60 \%$ & 3,645 \\
\hline Right P & $95 \%$ & $65 \%$ & 3,65 \\
\hline Diff $X$ & 2,08 & $70 \%$ & 3,655 \\
\hline Diff $P$ & $90 \%$ & $75 \%$ & 3,685 \\
\hline \#Errors & 0 & $80 \%$ & 3,695 \\
\hline Filter Min & Off & $85 \%$ & 3,725 \\
\hline Filter Max & Off & $90 \%$ & 4,195 \\
\hline \#Filtered & 0 & $95 \%$ & 4,195 \\
\hline
\end{tabular}

\begin{tabular}{|c|c|c|c|}
\hline Rank & Name & Lower & Upper \\
\hline 1 & Strategic perspectiv & 2,807525 & 3,36815 \\
\hline 2 & Strategic managem & 2,840325 & 3,3804 \\
\hline 3 & Vision and imaginat & 2,8321 & 3,3592 \\
\hline 4 & Understand failure I & 2,80795 & 3,3309875 \\
\hline 5 & Intuitiveness & 2,864625 & 3,381307143 \\
\hline 6 & Solve aesthetic and & 2,881666667 & 3,395825 \\
\hline 7 & Achieving (manager & 2,84125 & 3,3214 \\
\hline 8 & Complex problem si & 2,91275 & 3,334142857 \\
\hline & & & \\
\hline & & & \\
\hline & & & \\
\hline & & & \\
\hline & & & \\
\hline & & & \\
\hline
\end{tabular}

Figure A2. Screenshot of the simulation results for the "complex problem solving skills" cut-off score group. 
The probabilistic attitude changes the hierarchy of selection criteria for circular economy manager in construction projects in comparison to the deterministic approach. From this point of view, a closer look at the details of the simulation helps to understand the essence of this study.

\section{@RISK Output Report for COS3 = L29}

\section{Performed By: Jaroslaw Goreck}

Date: 17 Dec 2019
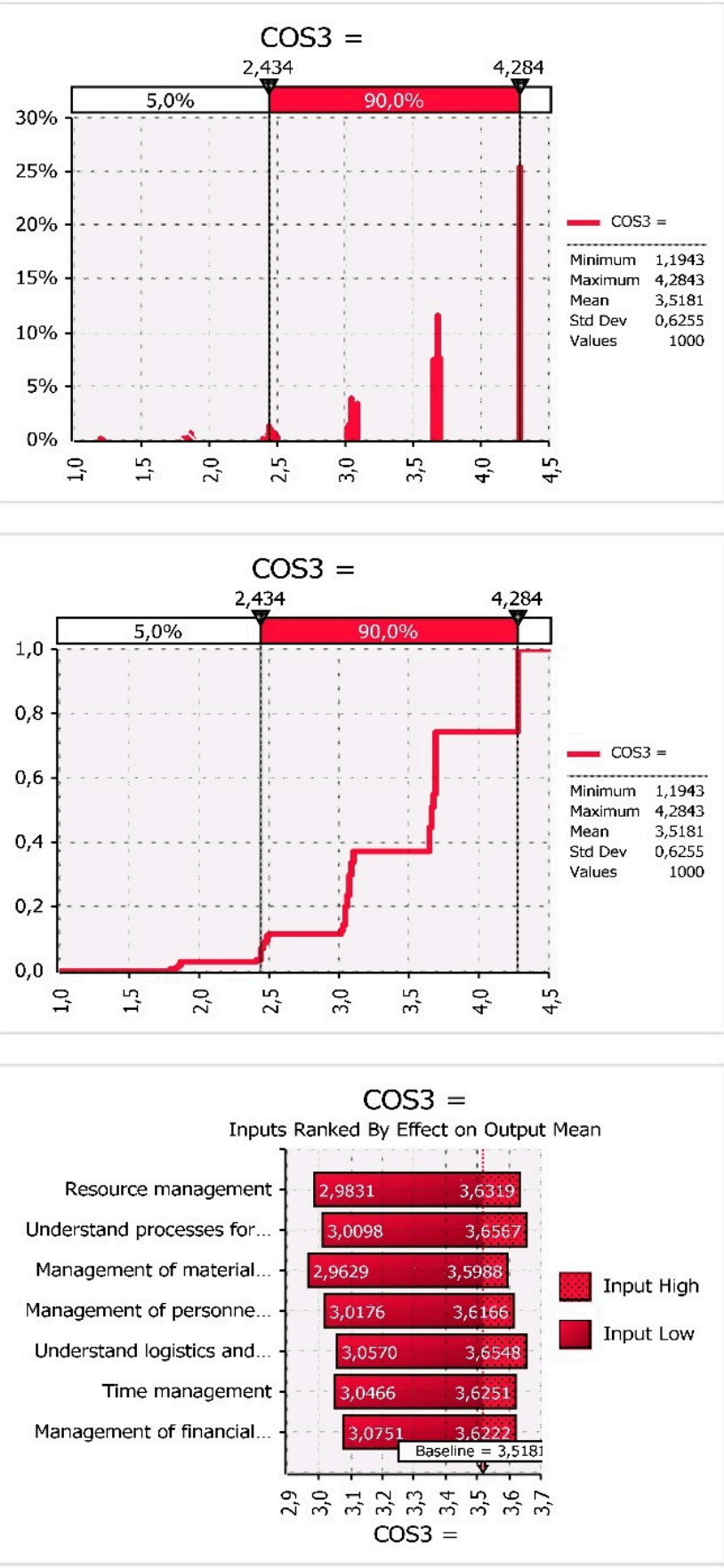

\begin{tabular}{|c|c|c|c|}
\hline \multicolumn{4}{|c|}{ Simulation Summary Information } \\
\hline \multicolumn{2}{|c|}{ Workbook Name } & \multicolumn{2}{|l|}{ model.xlsx } \\
\hline \multicolumn{2}{|c|}{ Number of Simulations } & \multicolumn{2}{|l|}{1} \\
\hline \multicolumn{2}{|c|}{ Number of Iterations } & \multicolumn{2}{|l|}{1000} \\
\hline \multicolumn{2}{|c|}{ Number of Inputs } & \multicolumn{2}{|l|}{68} \\
\hline \multicolumn{2}{|c|}{ Number of Outputs } & \multicolumn{2}{|l|}{6} \\
\hline \multicolumn{2}{|c|}{ Sampling Type } & \multicolumn{2}{|l|}{ Latin Hypercube } \\
\hline \multicolumn{2}{|c|}{ Simulation Start Time } & \multicolumn{2}{|c|}{ 2019-01-31 10:17 } \\
\hline \multicolumn{2}{|c|}{ Simulation Duration } & \multicolumn{2}{|c|}{$00: 08: 37$} \\
\hline \multicolumn{2}{|c|}{ Random \# Generator } & \multicolumn{2}{|c|}{ Mersenne Twister } \\
\hline \multicolumn{2}{|c|}{ Random Seed } & \multicolumn{2}{|c|}{526537960} \\
\hline \multicolumn{4}{|c|}{ Summary Statistics for COS3 = } \\
\hline \multicolumn{2}{|c|}{ Statistics } & \multicolumn{2}{|l|}{ Percentile } \\
\hline Minimum & 1,194285714 & $\mathbf{5 \%}$ & 2,434285714 \\
\hline Maximum & 4,284285714 & $10 \%$ & 2,478571429 \\
\hline Mean & 3,518104286 & $15 \%$ & 3,038571429 \\
\hline Std Dev & 0,625481361 & $20 \%$ & 3,051428571 \\
\hline Variance & 0,391226933 & $25 \%$ & 3,07 \\
\hline Skewness & $-0,632162061$ & $30 \%$ & 3,082857143 \\
\hline Kurtosis & 3,038069782 & $35 \%$ & 3,095714286 \\
\hline Median & 3,667142857 & $40 \%$ & 3,648571429 \\
\hline Mode & 4,284285714 & $45 \%$ & 3,667142857 \\
\hline Left $X$ & 2,434285714 & $50 \%$ & 3,667142857 \\
\hline Left $\mathbf{P}$ & $5 \%$ & $55 \%$ & 3,674285714 \\
\hline Right X & 4,284285714 & $60 \%$ & 3,687142857 \\
\hline Right $P$ & $95 \%$ & $65 \%$ & 3,687142857 \\
\hline Diff $X$ & 1,85 & $70 \%$ & 3,692857143 \\
\hline Diff $P$ & $90 \%$ & $75 \%$ & 4,284285714 \\
\hline \#Errors & 0 & $80 \%$ & 4,284285714 \\
\hline Filter Min & Off & $85 \%$ & 4,284285714 \\
\hline Filter Max & Off & $90 \%$ & 4,284285714 \\
\hline \#Filtered & 0 & $95 \%$ & 4,284285714 \\
\hline
\end{tabular}

\begin{tabular}{|c|c|c|c|}
\hline \multicolumn{4}{|c|}{ Change in Output Statistic for COS3 = } \\
\hline Rank & Name & Lower & Upper \\
\hline 1 & Resource managem & 2,983142857 & 3,631876786 \\
\hline 2 & Understand process & 3,009814286 & 3,656726531 \\
\hline 3 & Management of ma & 2,962871429 & 3,5988125 \\
\hline 4 & Management of per & 3,017571429 & 3,6166125 \\
\hline 5 & Understand logistic: & 3,056978571 & 3,654785714 \\
\hline 6 & Time management & 3,046628571 & 3,625094643 \\
\hline 7 & Management of fin: & 3,075142857 & 3,6222375 \\
\hline & & & \\
\hline & & & \\
\hline & & & \\
\hline & & & \\
\hline & & & \\
\hline & & & \\
\hline & & & \\
\hline
\end{tabular}

Figure A3. Screenshot of the simulation results for the "resource management skills" cut-off score group. 
@RISK Output Report for COS4 = L45

Performed By: Jaroslaw Gorecki

Date: 17 Dec 2019
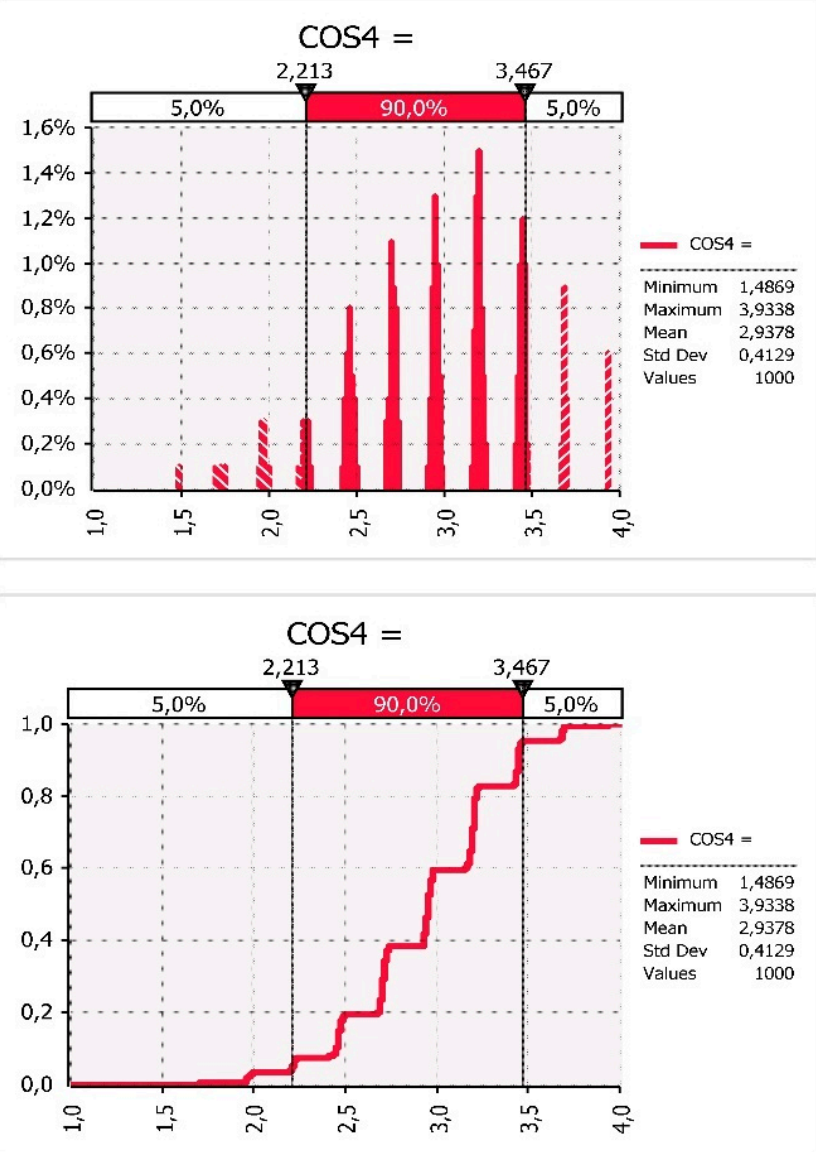

$\cos 4=$

Inputs Ranked By Effect on Output Mean

\begin{tabular}{|c|c|c|}
\hline \multirow{2}{*}{ Inspire followers to go be... } & \multirow{2}{*}{\multicolumn{2}{|c|}{ 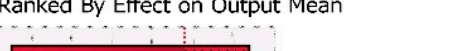 }} \\
\hline & & \\
\hline Interpersonal sensitivity & $2,7452 \quad 3,0270$ & \\
\hline Service orientation & 3,0151 & \\
\hline Developing (management) & 2,7569 & \\
\hline Influence & 2,7587 & Input $\mathrm{High}$ \\
\hline Instructing & 2,7616 & Input Low \\
\hline Interpersonal competence & 2,7776 & \\
\hline Developing followers into... & 2,7692 & \\
\hline Conscientiousness & \begin{tabular}{|l|l}
2,7773 & 2,9980 \\
\end{tabular} & \\
\hline Normative competence & 2,7 Baseline $=2,93783$ & \\
\hline & 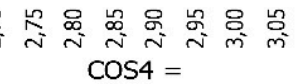 & \\
\hline
\end{tabular}

Simulation Summary Information

\begin{tabular}{l|l} 
Workbook Name & model.xlsx \\
\hline Number of Simulations & 1 \\
\hline Number of Iterations & 1000 \\
\hline Number of Inputs & 68 \\
\hline Number of Outputs & 6 \\
\hline Sampling Type & Latin Hypercube \\
\hline Simulation Start Time & $2019-01-31$ 10:17 \\
\hline Simulation Duration & $00: 08: 37$ \\
\hline Random \# Generator & Mersenne Twister \\
\hline Random Seed & 526537960 \\
\hline
\end{tabular}

\begin{tabular}{|c|c|c|c|}
\hline \multicolumn{4}{|c|}{ Summary Statistics for $\cos 4=$} \\
\hline \multicolumn{2}{|c|}{ Statistics } & \multicolumn{2}{|l|}{ Percentile } \\
\hline Minimum & 1,486875 & $\mathbf{5 \%}$ & 2,213125 \\
\hline Maximum & 3,93375 & $10 \%$ & 2,450625 \\
\hline Mean & 2,937826875 & $15 \%$ & 2,47 \\
\hline Std Dev & 0,412927459 & $20 \%$ & 2,68 \\
\hline Variance & 0,170509086 & $25 \%$ & 2,700625 \\
\hline Skewness & $-0,34407529$ & $30 \%$ & 2,71 \\
\hline Kurtosis & 2,939333099 & $35 \%$ & 2,72375 \\
\hline Median & 2,95375 & $40 \%$ & 2,930625 \\
\hline Mode & 3,20375 & $45 \%$ & 2,94375 \\
\hline Left $X$ & 2,213125 & $50 \%$ & 2,95375 \\
\hline Left P & $5 \%$ & $55 \%$ & 2,966875 \\
\hline Right $\mathrm{X}$ & 3,466875 & $60 \%$ & 3,164375 \\
\hline Right P & $95 \%$ & $65 \%$ & 3,1875 \\
\hline Diff $X$ & 1,25375 & $70 \%$ & 3,196875 \\
\hline Diff $\mathbf{P}$ & $90 \%$ & $75 \%$ & 3,20375 \\
\hline \#Errors & 0 & $80 \%$ & 3,21375 \\
\hline Filter Min & Off & $85 \%$ & 3,43375 \\
\hline Filter Max & Off & $90 \%$ & 3,44375 \\
\hline \#Filtered & 0 & $95 \%$ & 3,466875 \\
\hline
\end{tabular}

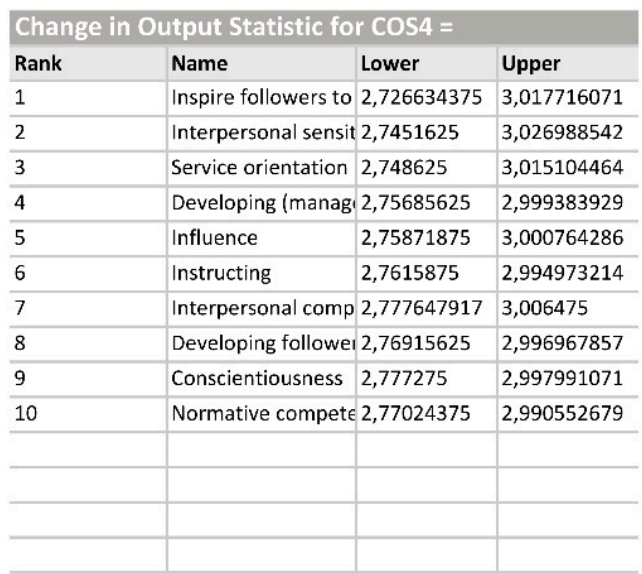

Figure A4. Screenshot of the simulation results for the "social skills" cut-off score group. 
@RISK Output Report for COS5 = L55

Performed By: Jaroslaw Gorecki

Date: 17 Dec 2019
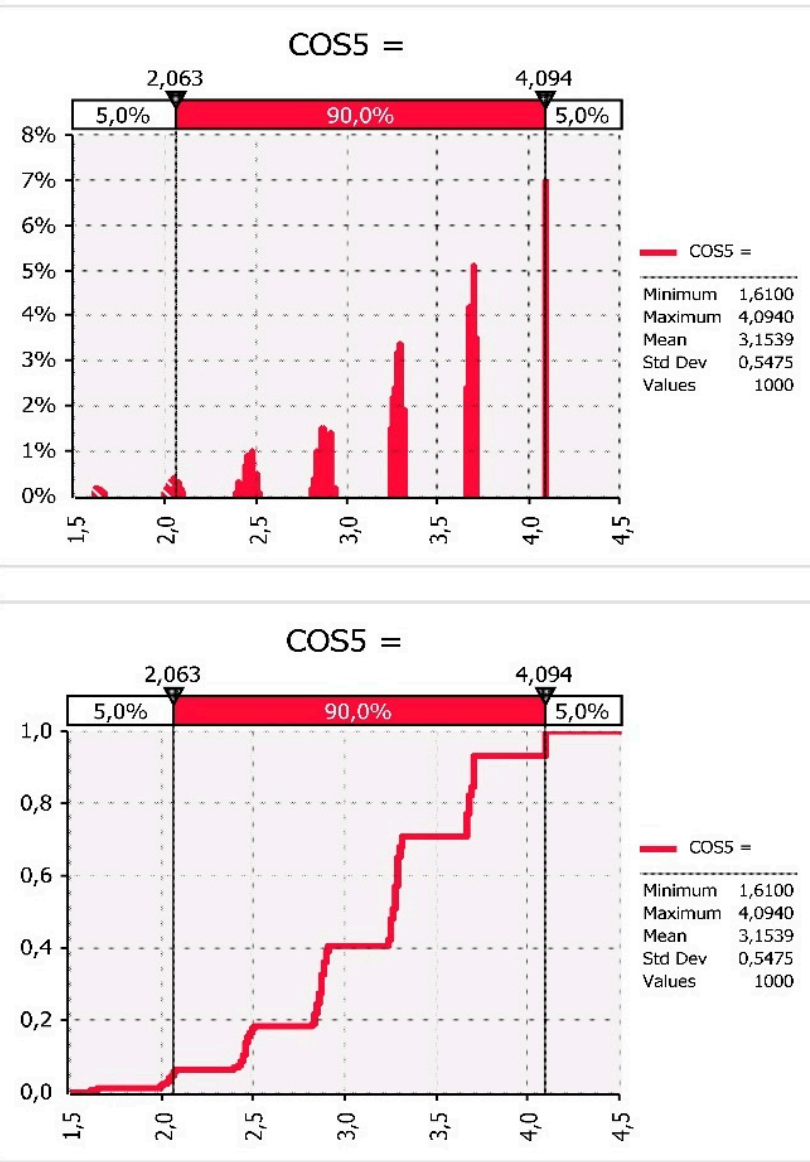

\begin{tabular}{l|l|}
\hline Simulation Summary Information \\
\hline Workbook Name & model.xlsx \\
\hline Number of Simulations & 1 \\
\hline Number of Iterations & 1000 \\
\hline Number of Inputs & 68 \\
\hline Number of Outputs & 6 \\
\hline Sampling Type & Latin Hypercube \\
\hline Simulation Start Time & $2019-01-31$ 10:17 \\
\hline Simulation Duration & $00: 08: 37$ \\
\hline Random \# Generator & Mersenne Twister \\
\hline Random Seed & 526537960 \\
\hline
\end{tabular}

\begin{tabular}{l|l|r|l}
\hline $\begin{array}{l}\text { Summary Statistics for COS5 } \\
\text { Statistics }\end{array}$ & \multicolumn{2}{l}{ Percentile } \\
\hline Minimum & 1,61 & $\mathbf{5 \%}$ & 2,063 \\
\hline Maximum & 4,094 & $\mathbf{1 0} \%$ & 2,447 \\
\hline Mean & 3,153882 & $\mathbf{1 5} \%$ & 2,473 \\
\hline Std Dev & 0,547481282 & $\mathbf{2 0} \%$ & 2,831 \\
\hline Variance & 0,299735754 & $\mathbf{2 5} \%$ & 2,857 \\
\hline Skewness & $-0,424242228$ & $\mathbf{3 0} \%$ & 2,873 \\
\hline Kurtosis & 2,817888035 & $\mathbf{3 5} \%$ & 2,889 \\
\hline Median & 3,263 & $\mathbf{4 0 \%}$ & 2,911 \\
\hline Mode & 4,094 & $\mathbf{4 5} \%$ & 3,252 \\
\hline Left X & 2,063 & $\mathbf{5 0} \%$ & 3,263 \\
\hline Left P & $5 \%$ & $\mathbf{5 5} \%$ & 3,279 \\
\hline Right X & 4,094 & $\mathbf{6 0} \%$ & 3,289 \\
\hline Right P & $95 \%$ & $\mathbf{6 5} \%$ & 3,294 \\
\hline Diff X & 2,031 & $\mathbf{7 0} \%$ & 3,321 \\
\hline Diff P & $90 \%$ & $\mathbf{7 5} \%$ & 3,668 \\
\hline \#Errors & 0 & $\mathbf{8 0} \%$ & 3,678 \\
\hline Filter Min & Off & $\mathbf{8 5} \%$ & 3,705 \\
\hline Filter Max & Off & $\mathbf{9 0} \%$ & 3,71 \\
\hline \#Filtered & 0 & $\mathbf{9 5} \%$ & 4,094 \\
\hline
\end{tabular}

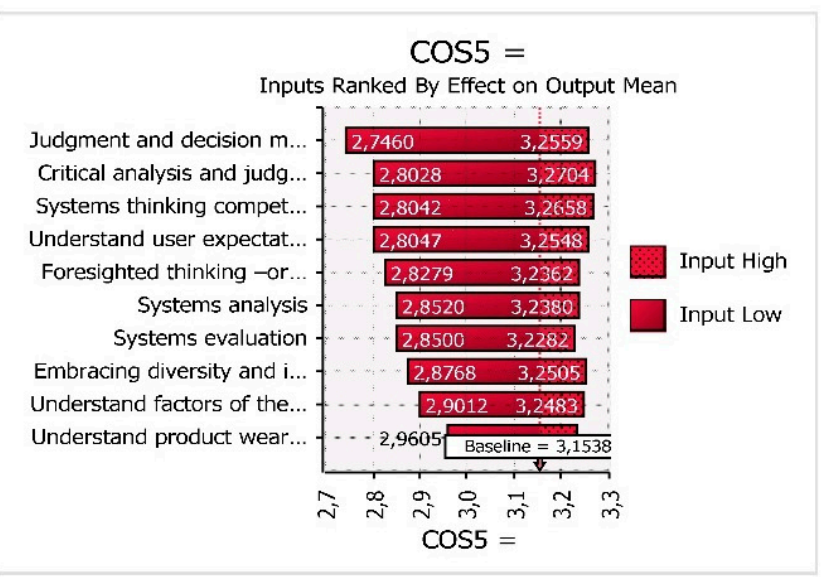

\begin{tabular}{|c|c|c|c|}
\hline \multicolumn{4}{|c|}{ Change in Output Statistic for COS5 = } \\
\hline Rank & Name & Lower & Upper \\
\hline 1 & Judgment and decis & $=2,746005$ & 3,25585125 \\
\hline 2 & Critical analysis and & 2,8028 & 3,27043 \\
\hline 3 & Systems thinking co & 2,80424 & 3,26581 \\
\hline 4 & Understand user ex & 2,804715 & 3,254791429 \\
\hline 5 & Foresighted thinkin: & 2,827875 & 3,236201429 \\
\hline 6 & Systems analysis & 2,852 & 3,238015714 \\
\hline 7 & Systems evaluation & 2,85004 & 3,22817875 \\
\hline 8 & Embracing diversity & 2,8768 & 3,250482857 \\
\hline 9 & Understand factors & 2,901225 & 3,248325714 \\
\hline 10 & Understand produc & 2,96046 & 3,230261429 \\
\hline & & & \\
\hline & & & \\
\hline & & & \\
\hline & & & \\
\hline
\end{tabular}

Figure A5. Screenshot of the simulation results for the "systems skills" cut-off score group. 
@RISK Output Report for COS6 = L69

Performed By: Jaroslaw Gorecki

Date: 17 Dec 2019

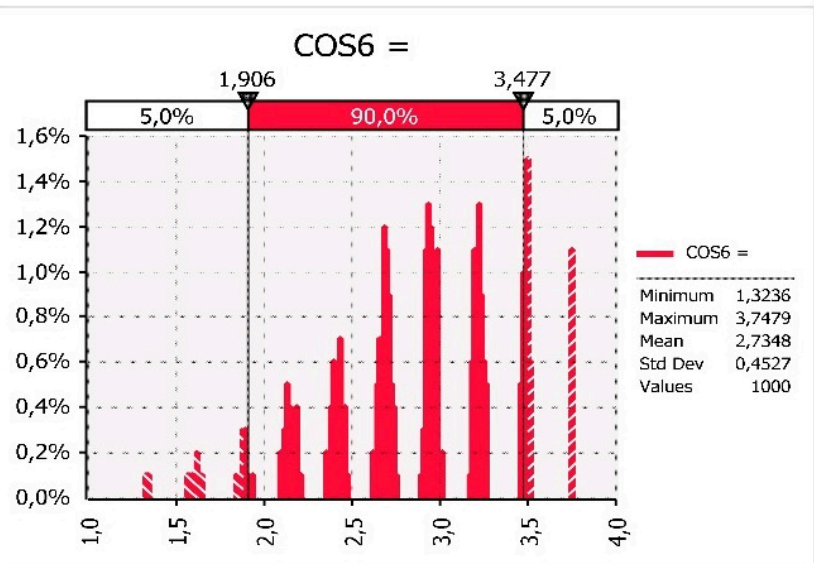

\begin{tabular}{l|l}
\hline \multicolumn{2}{l}{ Simulation Summary Information } \\
\hline Workbook Name & model.xlsx \\
\hline Number of Simulations & 1 \\
\hline Number of Iterations & 1000 \\
\hline Number of Inputs & 68 \\
\hline Number of Outputs & 6 \\
\hline Sampling Type & Latin Hypercube \\
\hline Simulation Start Time & $2019-01-31$ 10:17 \\
\hline Simulation Duration & $00: 08: 37$ \\
\hline Random \# Generator & Mersenne Twister \\
\hline Random Seed & 526537960 \\
\hline
\end{tabular}

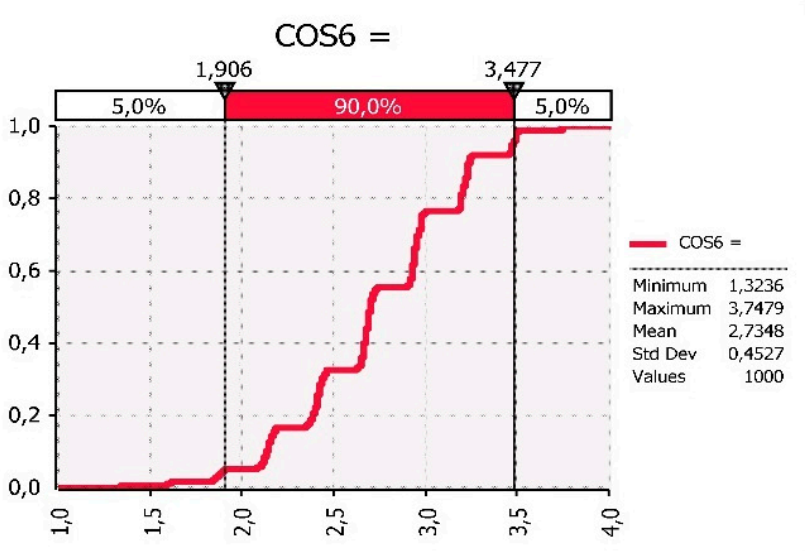

\begin{tabular}{l|l|r|l|}
$\begin{array}{l}\text { Summary Statistics for COS6 } \\
\text { Statistics }\end{array}$ & \multicolumn{3}{l}{ Percentile } \\
\hline Minimum & 1,323571429 & $\mathbf{5} \%$ & 1,905714286 \\
\hline Maximum & 3,747857143 & $\mathbf{1 0} \%$ & 2,138571429 \\
\hline Mean & 2,734767857 & $\mathbf{1 5} \%$ & 2,176428571 \\
\hline Std Dev & 0,452671925 & $\mathbf{2 0} \%$ & 2,390714286 \\
\hline Variance & 0,204911872 & $\mathbf{2 5} \%$ & 2,416428571 \\
\hline Skewness & $-0,25300894$ & $\mathbf{3 0} \%$ & 2,439285714 \\
\hline Kurtosis & 2,769873925 & $\mathbf{3 5} \%$ & 2,653571429 \\
\hline Median & 2,702857143 & $\mathbf{4 0 \%}$ & 2,672142857 \\
\hline Mode & 3,495714286 & $\mathbf{4 5} \%$ & 2,683571429 \\
\hline Left X & 1,905714286 & $\mathbf{5 0 \%}$ & 2,702857143 \\
\hline Left P & $5 \%$ & $\mathbf{5 5} \%$ & 2,736428571 \\
\hline Right X & 3,477142857 & $\mathbf{6 0} \%$ & 2,928571429 \\
\hline Right P & $95 \%$ & $\mathbf{6 5} \%$ & 2,943571429 \\
\hline Diff X & 1,571428571 & $\mathbf{7 0} \%$ & 2,958571429 \\
\hline Diff P & $90 \%$ & $\mathbf{7 5 \%}$ & 2,984285714 \\
\hline \#Errors & 0 & $\mathbf{8 0} \%$ & 3,199285714 \\
\hline Filter Min & Off & $\mathbf{8 5} \%$ & 3,221428571 \\
\hline Filter Max & Off & $\mathbf{9 0 \%}$ & 3,24 \\
\hline \#Filtered & 0 & $\mathbf{9 5} \%$ & 3,477142857 \\
\hline
\end{tabular}

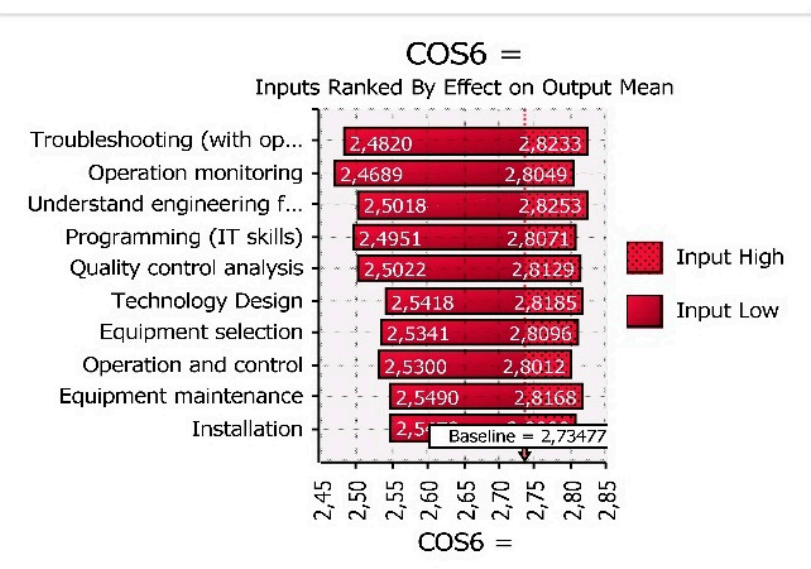

\begin{tabular}{|c|c|c|c|}
\hline Rank & Name & Lower & Upper \\
\hline 1 & Troubleshooting $(\mathrm{w}$ & 2,481982143 & 2,823285714 \\
\hline 2 & Operation monitori & i) 2,468932143 & 2,804921429 \\
\hline 3 & Understand enginet & 2,501810714 & 2,825328571 \\
\hline 4 & Programming (IT ski & 2,495057143 & 2,807078571 \\
\hline 5 & Quality control anal & 2,502242857 & 2,812881633 \\
\hline 6 & Technology Design & 2,54175 & 2,818530952 \\
\hline 7 & Equipment selectio & 2,534132143 & 2,809559184 \\
\hline 8 & Operation and cont & 2,530028571 & 2,801195918 \\
\hline 9 & Equipment mainten & 2,549014286 & 2,816847619 \\
\hline 10 & Installation & 2,547796429 & 2,808960204 \\
\hline & & & \\
\hline & & & \\
\hline & & & \\
\hline
\end{tabular}

Figure A6. Screenshot of the simulation results for the "technical skills" cut-off score group.

\section{References}

1. Schmelzer, M. The growth paradigm: History, hegemony, and the contested making of economic growthmanship. Ecol. Econ. 2015, 118, 262-271. [CrossRef]

2. Hamilton, C. Consumerism, self-creation and prospects for a new ecological consciousness. J. Clean. Prod. 2010, 18, 571-575. [CrossRef]

3. Panov, V.I. Ecological Thinking, Consciousness, Responsibility. Procedia-Soc. Behav. Sci. 2013, 86, $379-383$. [CrossRef] 
4. Research and Degrowth. Degrowth Declaration of the Paris 2008 conference. J. Clean. Prod. 2010, 18, 523-524. [CrossRef]

5. Luo, Z.; Dubey, R.; Gunasekaran, A.; Childe, S.J.; Papadopoulos, T.; Hazen, B.; Roubaud, D. Sustainable production framework for cement manufacturing firms: A behavioural perspective. Renew. Sustain. Energy Rev. 2017, 78, 495-502. [CrossRef]

6. Alayón, C.; Säfsten, K.; Johansson, G. Conceptual sustainable production principles in practice: Do they reflect what companies do? J. Clean. Prod. 2017, 141, 693-701. [CrossRef]

7. Górecki, J.; Swoiński, E.; Bizon-Górecka, J. Sustainable production: In search of european model for reducing environmental impact. In Innovation Management and Education Excellence Through Vision 2020; Soliman, K., Ed.; IBIMA: Milan, Italy, 2018; Volumes I-XI, pp. 1570-1578.

8. Czaplicka-Kolarz, K.; Kruczek, M.; Burchart-Korol, D. Eco-Efficiency Concept for Sustainable Production Management. In Scientific Papers of Silesian University of Technology; Organization and Management Series; Silesian University of Technology: Zabrze, Poland, 2013; pp. 59-71.

9. Brissaud, D.; Frein, Y.; Rocchi, V. What tracks for sustainable production systems in Europe? Procedia CIRP 2013, 7, 9-16. [CrossRef]

10. Zore, Ž.; Čuček, L.; Kravanja, Z. Synthesis of sustainable production systems using an upgraded concept of sustainability profit and circularity. J. Clean. Prod. 2018, 201, 1138-1154. [CrossRef]

11. Pla-Julián, I.; Guevara, S. Is circular economy the key to transitioning towards sustainable development? Challenges from the perspective of care ethics. Futures 2018, 105, 67-77. [CrossRef]

12. Gerwin, M. Sustainable Development Plan for Poland, Local Development Initiatives; Local Development Initiatives: Sopot, Poland, 2008.

13. Witjes, S.; Lozano, R. Towards a more Circular Economy: Proposing a framework linking sustainable public procurement and sustainable business models. Resour. Conserv. Recycl. 2016, 112, 37-44. [CrossRef]

14. Núñez-Cacho, P.; Molina-Moreno, V.; Corpas-Iglesias, F.A.; Cortés-García, F.J. Family Businesses Transitioning to a Circular Economy Model: The Case of "Mercadona". Sustainability 2018, 10, 538. [CrossRef]

15. Nuñez-Cacho, P.; Górecki, J.; Molina-Moreno, V.; Corpas-Iglesias, F. What Gets Measured, Gets Done: Development of a Circular Economy Measurement Scale for Building Industry. Sustainability 2018, 10, 2340. [CrossRef]

16. Kirchherr, J.; Piscicelli, L.; Bour, R.; Kostense-Smit, E.; Muller, J.; Huibrechtse-Truijens, A.; Hekkert, M. Barriers to the Circular Economy: Evidence From the European Union (EU). Ecol. Econ. 2018, 150, $264-272$. [CrossRef]

17. Suárez-Eiroa, B.; Fernández, E.; Méndez-Martínez, G.; Soto-Oñate, D. Operational principles of circular economy for sustainable development: Linking theory and practice. J. Clean. Prod. 2019, 214, 952-961. [CrossRef]

18. European Commission. Communication of the Commission to the European Parliament, the Council of the European Economic and Social Committee and the Committee of the Regions, Closing the Loop-VAn EU action plan for the Circular Economy; European Commission: Brussels, Belgium, 2015.

19. Kim, D.H.; Lin, S.C. Human capital and natural resource dependence. Struct. Chang. Econ. Dyn. 2017, 40, 92-102. [CrossRef]

20. Shahbaz, M.; Destek, M.A.; Okumus, I.; Sinha, A. An empirical note on comparison between resource abundance and resource dependence in resource abundant countries. Resour. Policy 2019, 60, 47-55. [CrossRef]

21. Barrett, J.; Cooper, T.; Hammond, G.P.; Pidgeon, N. Industrial energy, materials and products: UK decarbonisation challenges and opportunities. Appl. Therm. Eng. 2018, 136, 643-656. [CrossRef]

22. Cooper, S.J.G.; Giesekam, J.; Hammond, G.P.; Norman, J.B.; Owen, A.; Rogers, J.G.; Scott, K. Thermodynamic insights and assessment of the 'circular economy'. J. Clean. Prod. 2017, 162, 1356-1367. [CrossRef]

23. Whicher, A.; Harris, C.; Beverley, K.; Swiatek, P. Design for circular economy: Developing an action plan for Scotland. J. Clean. Prod. 2018, 172, 3237-3248. [CrossRef]

24. de Abreu, M.C.S.; Ceglia, D. On the implementation of a circular economy: The role of institutional capacity-building through industrial symbiosis. Resour. Conserv. Recycl. 2018, 138, 99-109. [CrossRef]

25. Sousa-Zomer, T.T.; Magalhães, L.; Zancul, E.; Campos, L.M.S.; Cauchick-Miguel, P.A. Cleaner production as an antecedent for circular economy paradigm shift at the micro-level: Evidence from a home appliance manufacturer. J. Clean. Prod. 2018, 185, 740-748. [CrossRef] 
26. Hurlimann, A.C.; Browne, G.R.; Warren-Myers, G.; Francis, V. Barriers to climate change adaptation in the Australian construction industry-Impetus for regulatory reform. Build. Environ. 2018, 137, 235-245. [CrossRef]

27. Heffernan, E.; Pan, W.; Liang, X.; de Wilde, P. Zero carbon homes: Perceptions from the UK construction industry. Energy Policy 2015, 79, 23-36. [CrossRef]

28. Tam, C.M.; Tam, V.W.Y.; Tsui, W.S. Green construction assessment for environmental management in the construction industry of Hong Kong. Int. J. Proj. Manag. 2004, 22, 563-571. [CrossRef]

29. Zuo, J.; Read, B.; Pullen, S.; Shi, Q. Achieving carbon neutrality in commercial building developments-Perceptions of the construction industry. Habitat Int. 2012, 36, 278-286. [CrossRef]

30. De Wolf, C.; Pomponi, F.; Moncaster, A. Measuring embodied carbon dioxide equivalent of buildings: A review and critique of current industry practice. Energy Build. 2017, 140, 68-80. [CrossRef]

31. Zuo, J.; Rameezdeen, R.; Hagger, M.; Zhou, Z.; Ding, Z. Dust pollution control on construction sites: Awareness and self-responsibility of managers. J. Clean. Prod. 2017, 166, 312-320. [CrossRef]

32. Ajayi, S.O.; Oyedele, L.O.; Bilal, M.; Akinade, O.O.; Alaka, H.A.; Owolabi, H.A.; Kadiri, K.O. Waste effectiveness of the construction industry: Understanding the impediments and requisites for improvements. Resour. Conserv. Recycl. 2015, 102, 101-112. [CrossRef]

33. Ajayi, S.O.; Oyedele, L.O.; Akinade, O.O.; Bilal, M.; Owolabi, H.A.; Alaka, H.A.; Kadiri, K.O. Reducing waste to landfill: A need for cultural change in the UK construction industry. J. Build. Eng. 2016, 5, 185-193. [CrossRef]

34. Ajayi, S.O.; Oyedele, L.O.; Akinade, O.O.; Bilal, M.; Alaka, H.A.; Owolabi, H.A. Optimising material procurement for construction waste minimization: An exploration of success factors. Sustain. Mater. Technol. 2017, 11, 38-46. [CrossRef]

35. Gbadamosi, A.-Q.; Mahamadu, A.-M.; Oyedele, L.O.; Akinade, O.O.; Manu, P.; Mahdjoubi, L.; Aigbavboa, C. Offsite Construction: Developing a BIM-Based Optimizer for Assembly. J. Clean. Prod. 2019, 215, 1180-1190. [CrossRef]

36. Burger, M.; Stavropoulos, S.; Ramkumar, S.; Dufourmont, J.; van Oort, F. The heterogeneous skill-base of circular economy employment. Res. Policy 2018, 48, 248-261. [CrossRef]

37. Górecki, J.; Núñez-Cacho, P.; Corpas-Iglesias, F.A.; Molina, V. How to convince players in construction market? Strategies for effective implementation of Circular Economy in construction sector. Cogent Eng. 2019, 6, 6. [CrossRef]

38. City of Amsterdam; Circle Economy; Kate Raworth. Building Blocks for the New Strategy Amsterdam Circular 2020-2025; City of Amsterdam; Circle Economy; Kate Raworth: Amsterdam, The Netherland, 2019.

39. Núñez-Cacho, P.; Górecki, J.; Molina-Moreno, V.; Corpas-Iglesias, F.A. New Measures of Circular Economy Thinking In Construction Companies. J. EU Res. Bus. 2018, 2018, 909360. [CrossRef]

40. Plebankiewicz, E.; Zima, K.; Wieczorek, D. Life Cycle Cost Modelling of Buildings with Consideration of the Risk. Arch. Civ. Eng. 2016, 62, 149-166. [CrossRef]

41. Górecki, J. Circular Economy Maturity in Construction Companies. IOP Conf. Ser. Mater. Sci. Eng. 2018, 471, 112090. [CrossRef]

42. Leśniak, A.; Zima, K. Cost calculation of construction projects including sustainability factors using the Case Based Reasoning (CBR) method. Sustainability 2018, 10, 1608. [CrossRef]

43. Shahhosseini, V.; Sebt, M.H. Competency-based selection and assignment of human resources to construction projects. Sci. Iran. 2011, 18, 163-180. [CrossRef]

44. Kabak, M. A fuzzy DEMATEL-ANP based multi criteria decision making approach for personnel selection. J. Mult.-Valued Log. Soft Comput. 2013, 20, 571-593.

45. Zavadskas, E.K.; Vainiunas, P.; Turskis, Z.; Tamosaitiene, J. Multiple Criteria Decision Support system for assessment of projects managers in construction. Int. J. Inf. Technol. Decis. Mak. 2012, 11, 501-520. [CrossRef]

46. Karabasevic, D.; Zavadskas, E.K.; Turskis, Z.; Stanujkic, D. The framework for the selection of personnel based on the SWARA and ARAS methods under uncertainties. Informatica 2016, 27, 49-65. [CrossRef]

47. Dursun, M.; Karsak, E.E. A fuzzy MCDM approach for personnel selection. Expert Syst. Appl. 2010, 37, 4324-4330. [CrossRef]

48. Polychroniou, P.V.; Giannikos, I. A fuzzy multicriteria decision-making methodology for selection of human resources in a Greek private bank. Career Dev. Int. 2009, 14, 372-387. [CrossRef] 
49. Safarzadegan Gilan, S.; Sebt, M.H.; Shahhosseini, V. Computing with words for hierarchical competency based selection of personnel in construction companies. Appl. Soft Comput. 2012, 12, 860-871. [CrossRef]

50. Afshari, A.R.; Mojahed, M.; Yusuff, R.M. Simple Additive Weighting approach to personnel selection problem. Int. J. Innov. Manag. Technol. 2010, 1, 511-515.

51. Afshari, A.R.; Yusuff, R.; Derayatifar, A.R. Project manager selection by using Fuzzy Simple Additive Weighting method. In Proceedings of the 2012 International Conference on Innovation Management and Technology Research, Malacca, Malaysia, 21-22 May 2012; pp. 412-416.

52. Zavadskas, E.K.; Turskis, Z.; Tamošaitienè, J.; Marina, V. Selection of construction project managers by applying COPRAS-G method. Comput. Model. New Technol. 2008, 12, 22-28.

53. Kelemenis, A.; Askounis, D. A new TOPSIS-based multi-criteria approach to personnel selection. Expert Syst. Appl. 2010, 37, 4999-5008. [CrossRef]

54. Afshari, A.R. Methods for selection of construction project manager: Case study. J. Constr. Eng. Manag. 2017, 143, 06017003. [CrossRef]

55. Afshari, A.R. Selection of construction project manager by using Delphi and fuzzy linguistic decision making. J. Intell. Fuzzy Syst. 2015, 28, 2827-2838. [CrossRef]

56. Sadatrasool, M.; Bozorgi-Amiri, A.; Yousefi-Babadi, A. Project manager selection based on project manager competency model: PCA-MCDM Approach. J. Proj. Manag. 2016, 1, 7-20. [CrossRef]

57. Liu, H.-C.; Qin, J.-T.; Mao, L.-X.; Zhang, Z.-Y. Personnel selection using interval 2-tuple linguistic VIKOR method. Hum. Factors Ergon. Manuf. 2015, 25, 370-381. [CrossRef]

58. Chen, P.-C. A fuzzy Multiple Criteria Decision Making model in employee recruitment. Int. J. Comput. Sci. Netw. Secur. 2009, 9, 113-117.

59. Fahmy Aly, M.; Abd El-hameed, H.M. Integrating AHP and genetic algorithm model adopted for personal selection. Int. J. Eng. Trends Technol. 2013, 6, 247-256.

60. Güngör, Z.; Serhadlığlu, G.; Kesen, S.E. A fuzzy AHP approach to personnel selection problem. Appl. Soft Comput. 2009, 9, 641-646. [CrossRef]

61. Taylor, F.A.; Ketcham, A.F.; Hoffman, D. Personnel evaluation with AHP. Manag. Decis. 1998, 36, 679-685. [CrossRef]

62. Zavadskas, E.K.; Turskis, Z.; Tamošaitienè, J.; Marina, V. Multicriteria selection of project managers by applying grey criteria. Technol. Econ. Dev. Econ. 2008, 14, 462-477. [CrossRef]

63. Boran, S.; Göztepe, K.; Yavuz, E. A study on election of personnel based on performance measurement by using Analytic Network Process (ANP). Int. J. Comput. Sci. Netw. Secur. 2008, 8, 333-338.

64. Varajão, J.; Cruz-Cunha, M.M. Using AHP and the IPMA Competence Baseline in the project managers selection process. Int. J. Prod. Res. 2013, 51, 3342-3354. [CrossRef]

65. Zhao, L.; Guo, Y.; Cui, W. The application of fuzzy comprehensive evaluation methods in the selection of a project manager. In Proceedings of the 2009 Fourth International Conference on Computer Sciences and Convergence Information Technology, Seoul, Korea, 24-26 November 2009; pp. 1387-1391.

66. Rashidi, A.; Jazebi, F.; Brilakis, I. Neurofuzzy Genetic System for Selection of Construction Project Managers. J. Constr. Eng. Manag. 2011, 137, 17-29. [CrossRef]

67. Jazebi, F.; Rashidi, A. An automated procedure for selecting project managers in construction firms. J. Civ. Eng. Manag. 2013, 19, 97-106. [CrossRef]

68. Zhao, H.; Wang, X.-Q.; Yu, G.; Zhang, L.-F. Study on engineering project manager selection. In Proceedings of the 2008 4th International Conference on Wireless Communications, Networking and Mobile Computing, Dalian, China, 12-17 October 2008; pp. 1-4.

69. Hadad, Y.; Keren, B.; Laslo, Z. A decision-making support system module for project manager selection according to past performance. Int. J. Proj. Manag. 2013, 31, 532-541. [CrossRef]

70. Lin, H.-T. Personnel selection using analytic network process and fuzzy data envelopment analysis approaches. Comput. Ind. Eng. 2010, 59, 937-944. [CrossRef]

71. Turskis, Z.; Zavadskas, E.K. A novel method for multiple criteria analysis: Grey Additive Ratio Assessment (ARAS-G) method. Informatica 2010, 21, 597-610.

72. Baležentis, A.; Baležentis, T.; Brauers, W.K.M. Personnel selection based on computing with words and fuzzy MULTIMOORA. Expert Syst. Appl. 2012, 39, 7961-7967. [CrossRef]

73. Kabak, M.; Burmaoğlu, S.; Kazançoğlu, Y. A fuzzy hybrid MCDM approach for professional selection. Expert Syst. Appl. 2012, 39, 3516-3525. [CrossRef] 
74. Dağdeviren, M. A hybrid multi-criteria decision-making model for personnel selection in manufacturing systems. J. Intell. Manuf. 2010, 21, 451-460. [CrossRef]

75. Jafarnejad Chaghooshi, A.; Arab, A.; Hosseini Dehshiri, S.J. A fuzzy hybrid approach for project manager selection. Decis. Sci. Lett. 2016, 5, 447-460. [CrossRef]

76. Mohammadi, F.; Sadi, M.K.; Nateghi, F.; Abdullah, A.; Skitmore, M. A hybrid Quality Function Deployment and Cybernetic Analytic Network Process model for project manager selection. J. Civ. Eng. Manag. 2014, 20, 795-809. [CrossRef]

77. Kazan, H.; Özçelik, S.; Hobikoğlu, E.H. Election of deputy candidates for nomination with AHP-Promethee methods. Procedia-Soc. Behav. Sci. 2015, 195, 603-613. [CrossRef]

78. Keršuliene, V.; Zavadskas, E.K.; Turskis, Z. Selection of rational dispute resolution method by applying new step-wise weight assessment ratio analysis (SWARA). J. Bus. Econ. Manag. 2010, 11, 243-258. [CrossRef]

79. Karabasevic, D.; Stanujkic, D.; Urosevic, S.; Maksimovic, M. Selection of candidates in the mining industry based on the application of the SWARA and the MULTIMOORA methods. Acta Montan. Slovaca 2015, 20, 116-124.

80. Karabašević, D.; Stanujkić, D.; Urošević, S.; Maksimović, M. An approach to personnel selection based on SWARA and WASPAS methods. J. Econ. Manag. Inform. 2016, 7, 1-11.

81. Stanujkic, D.; Karabasevic, D.; Zavadskas, E.K. A new approach for selecting alternatives based on the adapted Weighted Sum and the SWARA methods: A case of personnel selection. Econ. Comput. Econ. Cybern. Stud. Res. 2017, 51, 39-56.

82. Zavadskas, E.K.; Turskis, Z.; Antucheviciene, J.; Zakarevicius, A. Optimization of weighted aggregated sum product assessment. Elektron. ir Elektrotechnika 2012, 122, 3-6. [CrossRef]

83. Kosareva, N.; Kazimieras Zavadskas, E.; Krylovas, A.; Dadelo, S. Personnel ranking and selection problem solution by application of KEMIRA method. Int. J. Comput. Commun. Control 2015, 11, 51. [CrossRef]

84. Xu, X. The SIR method: A superiority and inferiority ranking method for multiple criteria decision making. Eur. J. Oper. Res. 2001, 131, 587-602. [CrossRef]

85. Rezaei, J. Best-worst multi-criteria decision-making method. Omega 2015, 53, 49-57. [CrossRef]

86. Müller, R.; Turner, R. Leadership competency profiles of successful project managers. Int. J. Proj. Manag. 2010, 28, 437-448. [CrossRef]

87. Tabassi, A.A.; Roufechaei, K.M.; Ramli, M.; Bakar, A.H.A.; Ismail, R.; Pakir, A.H.K. Leadership competences of sustainable construction project managers. J. Clean. Prod. 2016, 124, 339-349. [CrossRef]

88. De los Rios, I.C.; Charnley, F.J.S. Skills and capabilities for a sustainable and circular economy: The changing role of design. J. Clean. Prod. 2017, 160, 109-122. [CrossRef]

89. Lambrechts, W.; Gelderman, C.J.; Semeijn, J.; Verhoeven, E. The role of individual sustainability competences in eco-design building projects. J. Clean. Prod. 2019, 208, 1631-1641. [CrossRef]

90. Sahakian, M.; Seyfang, G. A sustainable consumption teaching review: From building competencies to transformative learning. J. Clean. Prod. 2018, 198, 231-241. [CrossRef]

(C) 2019 by the author. Licensee MDPI, Basel, Switzerland. This article is an open access article distributed under the terms and conditions of the Creative Commons Attribution (CC BY) license (http://creativecommons.org/licenses/by/4.0/). 